\title{
Diabetes-induced Functional and Structural Changes in Insulin Receptors from Rat Skeletal Muscle
}

\author{
Charles F. Burant, Mary K. Treutelaar, and Maria G. Buse \\ Departments of Medicine and Biochemistry, Medical University of South Carolina, Charleston, South Carolina 29425
}

\begin{abstract}
The effect of diabetes on the structure and function of insulin receptors was studied in rats $7 \mathrm{~d}$ after streptozotocin injection, using solubilized, partially purified receptors from rat hindlimb muscles. Diabetes increased the number of insulin receptors per gram of muscle 60-70\% without apparent change in insulin binding affinity. Incubation of receptors at $4^{\circ} \mathrm{C}$ with $\left[\gamma-{ }^{32} \mathrm{P}\right] \mathrm{ATP}$ and insulin resulted in dose-dependent autophosphorylation of the $\boldsymbol{\beta}$-subunit on tyrosine residues; receptors from diabetic rats showed decreased base-line phosphorylation, as well as a decrease in autophosphorylation at maximally stimulating insulin concentrations. These receptors also showed diminished exogenous substrate kinase activity using histone $\mathrm{H}_{2} \mathrm{~b}$ and angiotensin II as phosphoacceptors. The electrophoretic mobility (sodium dodecyl sulfate-polyacrylamide gel electrophoresis) of a subpopulation of $\boldsymbol{\beta}$-subunits derived from diabetics was slightly decreased; differences in electrophoretic mobility between controland diabetic-derived $\beta$-subunits were enhanced by generating fragments by partial Staphylococcus aureus V8 protease digestion. Endoglycosidase-H or neuraminidase treatment increased the electrophoretic mobility of $\boldsymbol{\beta}$-subunits in both groups, but only neuraminidase appeared to decrease or abolish differences in electrophoretic mobility between controls and diabetics, suggesting that excess sialidation may account, in part, for the altered mobility of diabetic derived $\beta$-subunits. All structural and functional alterations in insulin receptors were prevented by treating diabetic rats with insulin for $60 \mathrm{~h}$. Peripheral insulin resistance associated with insulinopenic diabetes may be related to modifications in insulin receptor structure, resulting in impaired signal transmission.
\end{abstract}

\section{Introduction}

Insulinopenic diabetes in humans is associated with peripheral insulin resistance (1-4), which appears to be related to prior glycemic control (5). Using a closed-loop subcutaneous insulin infusion system, Mayfield et al. (5) reported a direct correlation between elevated hemoglobin $(\mathrm{Hb}) \mathrm{A}_{\mathrm{Ic}}$ levels and increased in-

Portions of this research were presented at the Annual Meeting of the Southern Society for Clinical Investigation, January 1985, and at the Annual Meeting of the American Federation for Clinical Research, April 1985.

Address reprint requests to Dr. Buse, Department of Medicine, Medical University of South Carolina, 171 Ashley Avenue, Charleston, SC 29425.

Received for publication 28 January 1985 and in revised form 26 July 1985 .

\footnotetext{
J. Clin. Invest.

(C) The American Society for Clinical Investigation, Inc. 0021-9738/86/01/0260/11 \$1.00

Volume 77, January 1986, 260-270
}

sulin requirements in type I diabetic patients. Strict control of blood glucose levels increased the subjects' sensitivity to insulin (5-7). Insulin resistance is also seen in animals with experimentally induced insulinopenia. Reaven et al. (8) observed insulin resistance in alloxan diabetic dogs when fasting plasma glucose levels exceeded $150 \mathrm{mg} / \mathrm{dl}$ whereas dogs with lower glycemia responded to insulin as the controls. In rodents, streptozotocininduced diabetes results in a diminished response to insulin in isolated adipocytes $(9-11)$, liver $(12,13)$, as well as skeletal $(14)$ and heart muscle (15), whereas insulin binding (e.g., the apparent number of insulin receptors) is increased $(9,10,13)$. This has led to the suggestion that the insulin resistance associated with poorly-controlled type I diabetes is primarily a postreceptor defect. Alternatively, it may represent a defect in signal transmission by the occupied insulin receptor.

The initial event in insulin action on target tissues is its binding to specific cell surface receptors. The insulin receptor is a heterotetramer glycoprotein, consisting of two $\alpha$ - and two $\beta$ subunits. The $\alpha$-subunit with an apparent molecular weight of $\left(\mathrm{MW}_{\text {app }}\right)^{1} \sim 135,000$ appears to contain the insulin-binding domain, whereas the $\beta$-subunit $\mathrm{MW}_{\text {app }} \sim 95,000$ may be primarily involved in signal transmission. Insulin binding induces the autophosphorylation of the $\beta$-subunit in both intact cells and in cell-free systems (16-23). After this autophosphorylation, the insulin receptor acquires the ability to act as a kinase toward exogenous substrates $(18,21,23)$. These phosphorylation events occur on tyrosine residues and have been suggested to trigger the phosphorylation-dephosphorylation cascade seen in cells upon exposure to insulin $(16,20,22)$.

Because skeletal muscle is an important site of insulin action, we investigated the effect of streptozotocin-induced diabetes on the functional and structural properties of the solubilized rat skeletal muscle insulin receptor. We found that the insulin-stimulated autophosphorylation and exogenous substrate kinase activity of diabetic-derived receptors was impaired. This alteration was reversed by in vivo insulin treatment. The functional changes were paralleled by the appearance of a subpopulation of insulin receptor $\beta$-subunits in diabetic skeletal muscle with a slower electrophoretic migration; the latter may reflect altered glycosylation of the $\beta$-subunit.

\section{Methods}

Materials. Streptozotocin was a gift from Dr. William Dulin, Upjohn Research Laboratories (Kalamazoo, MI). Polyclonal antiinsulin receptor antibody (A410) was a gift from Dr. Steven Jacobs, Wellcome Research Laboratories (Research Triangle Park, NC) and from Dr. C. Ronald Kahn (B9), Joslin Research Laboratories (Boston, MA). Monocompo-

1. Abbreviations used in this paper: DMSO, dimethyl sulfoxide; $\mathbf{M W}_{\mathrm{app}}$, apparent molecular weight; PAGE, polyacrylamide gel electrophoresis; PIC, protease inhibitor cocktail; PMSF, phenylmethylsulfonyl fluoride; TLC, thin-layer chromatography; TPCK, L-1-tosylamide-2-phenylethy chloromethyl ketone; WGA, wheat germ agglutinin. 
nent, crystalline pork insulin was a gift from Dr. Ronald Chance, Lilly Research Laboratories (Indianapolis, IN). Monoiodinated A14 ${ }^{125}$ I-insulin used in some studies was kindly provided by Dr. B. H. Frank, Lilly Research Laboratories. Wheat germ agglutinin (WGA) was from Vector Laboratories (Burlingame, CA); Aprotinin from FBA Pharmaceuticals (New York); Bacitracin from Pfizer (New York). Electrophoresis reagents were from Serva (Heidelberg, Federal Republic of Germany) and the apparatus was from LKB Instruments, Inc. (Houston, TX). Protein Abearing Staphylococcus aureus (Pansorbin) and neuraminidase (Vibrio cholera) were from Calbiochem-Behring Corp. (San Diego, CA). S. aureus V8 protease and endoglycosidase $\mathrm{H}$ were from Miles Laboratories, Inc. (Elkhart, IN). ${ }^{125}$ I-iodine was from New England Nuclear (Boston, MA). $\left[\gamma-{ }^{32} \mathrm{P}\right] \mathrm{ATP}$ was prepared from $\left[{ }^{32} \mathrm{P}\right]$ orthophosphate (ICN, Cambridge, MA) in Gammaprep vials (Promega Biotec, Madison, WI) as described by the manufacturer. Cyanogen bromide $(\mathrm{CNBr})$-Sepharose $4 \mathrm{~B}$ beads were from Pharmacia Fine Chemicals (Piscataway, NJ). Thin-layer chromatography (TLC) plates, Polygram CEL300, were from Brinkmann Instrument Co. (Westbury, NY). Autoradiography film, X-Omat AR was from Eastman Kodak Co. (Rochester, NY). Lightening + intensifying screens were from Dupont Co. (Wilmington, DE). All other reagents and chemicals were from Sigma Chemical Co. (St. Louis, MO) unless otherwise specified.

Animals. Male Wistar rats (Charles River Breeding Co., Wilmington, MA) $100-140 \mathrm{~g}$ of initial body weight were used in all experiments. They were allowed food and water ad libitum. Diabetes was induced by i.p. injection of streptozotocin in citrate buffer, $\mathrm{pH} 4.5,130 \mathrm{mg} / \mathrm{kg}$ of body weight, to overnight fasted animals. In insulin-reversal experiments, diabetic rats were initially treated with $2 U$ of regular and $2 U$ of protamine zinc insulin s.c. at $1700 \mathrm{~h}$ on the 5th day after streptozotocin and subsequently with $2 \mathrm{U}$ of protamine zinc insulin at 0900 and $1700 \mathrm{~h}$ the next $2 \mathrm{~d}$ for a total of five treatments. Glycosuria was monitored by TesTape (Eli Lilly Co.) and was 4+ in untreated diabetic rats, and trace, or negative in insulin-treated rats by the 2 nd day of treatment. Plasma glucose levels were determined with a Beckman Glucose Analyzer 2 (Beckman Instrument Co., Palo Alto, CA) on blood samples obtained when the animals were killed. Diabetic rats with or without insulin treatment were studied on the 7th day after streptozotocin, and compared to control animals. Rats were killed by decapitation, and the hindlimb muscles were rapidly removed and frozen in liquid nitrogen. Insulin receptors from control and experimental animal groups were always processed on the same day and analyzed in the same experiments.

Solubilization and partial insulin receptor purification were performed as previously described (23). Briefly, the frozen muscles, $\sim 5 \mathrm{~g}$, were powdered and membrane components were solubilized by homogenization as a frozen slurry in $4 \mathrm{vol}$ of $25 \mathrm{mM}$ Hepes, $\mathrm{pH} 7.4,5 \mathrm{mM}$ EDTA, $1 \mathrm{TIU} / \mathrm{ml}$ aprotinin, $2 \mathrm{mM}$ phenylmethylsulfonyl fluoride (PMSF), and $1 \%$ Triton X-100. The homogenate was centrifuged at $10,000 \mathrm{~g}$ for 10 min and the supernate was stirred at room temperature for $1 \mathrm{~h}$. The mixture was then centrifuged at $150,000 \mathrm{~g}$ for $90 \mathrm{~min}$. The receptors were further purified by adsorption to and elution from agarose-bound WGA. Receptors were eluted from the WGA column with $25 \mathrm{mM}$ Hepes, pH 7.4, $0.1 \%$ Triton X-100 containing $0.3 \mathrm{M} N$-acetylglucosamine ( $\sim 1$ $\mathrm{ml} / \mathrm{g}$ of original tissue weight) and used directly or further purified by precipitation with polyclonal antiinsulin receptor antibody. In some preparations ${ }^{125}$ I-insulin $(\sim 1.5 \mu \mathrm{Ci})$ was added after homogenization of muscles with or without $50 \mu \mathrm{g} / \mathrm{ml}$ unlabeled insulin. Aliquots were taken at various times during the isolation procedure, and ${ }^{125}$ I-insulin specifically bound was determined by polyethylene glycol precipitation. Recovery and trichloroacetic acid (TCA) precipitability of the ${ }^{125}$ I-insulin were determined by counting aliquots in a $\gamma$-counter as described below.

Insulin binding. WGA eluate $(50 \mu \mathrm{l})$ was incubated with $10,000 \mathrm{cpm}$ ${ }^{125}$ I-insulin (sp act $125-175 \mu \mathrm{Ci} / \mu \mathrm{g}$, prepared by the lactoperoxidase method as described in Reference 24) and with increasing concentrations of unlabeled insulin for $16 \mathrm{~h}$ at $4^{\circ} \mathrm{C}$ in a buffer containing $25 \mathrm{mM}$ Hepes, $0.1 \%$ Triton $\mathrm{X}-100,150 \mathrm{mM} \mathrm{NaCl}, 0.1 \%$ bovine serum albumin, and $100 \mathrm{U} / \mathrm{ml}$ Bacitracin as described by Taylor et al. (25). The receptor and bound insulin were precipitated by the addition of $100 \mu \mathrm{l}$ of $0.3 \%$ bovine $\gamma$-globulin and $300 \mu \mathrm{l}$ of $25 \%$ polyethylene glycol and collected by cen- trifugation. The resulting pellet was washed with $300 \mu \mathrm{l}$ of $12.5 \%$ polyethylene glycol and counted in a Beckman Instruments Gamma $\mathbf{4 0 0 0}$ $\gamma$ counter. Nonspecific binding (10-15\%) was estimated as that occurring in the presence of $10 \mu \mathrm{g} / \mathrm{ml}$ unlabeled insulin. Binding was related to the protein concentration in the WGA eluate estimated by the Bradford reaction (26).

Equalization of receptor number. In all experiments that assessed functional and structural properties of solubilized insulin receptors derived from experimental and control animals, approximately equal insulinbinding activity was used in comparing groups. Because no change in insulin-binding affinity was apparent in receptors from diabetic animals (see Results), equal numbers of insulin receptors were estimated as follows: ${ }^{125}$ I-insulin binding per $50 \mu \mathrm{l}$ of WGA eluate was determined in the presence of $1,5,25,100,1,000$, and $10,000 \mathrm{ng} / \mathrm{ml}$ unlabeled insulin (the latter used as estimate of nonspecific binding after overnight incubation at $4^{\circ} \mathrm{C}$ or $45 \mathrm{~min}$ at $25^{\circ} \mathrm{C}$ ). Ratios of the specifically bound counts in the experimental group vs. the control were determined at each insulin concentration, these ratios were averaged, and the mean value used as an estimate of relative number of insulin receptors. Individual values were within $10-15 \%$ of this mean. Appropriate volumes of the WGA eluate were then used in subsequent experiments. Identical ratios were obtained after overnight or 45 -min incubation with ${ }^{125}$ I-insulin; the latter resulted in $\sim 60-70 \%$ of the equilibrium binding obtained in the former. All dilutions of WGA eluate were made with $25 \mathrm{mM}$ Hepes, $\mathrm{pH} 7.4$, $0.1 \%$ Triton X-100. The presence of $0.3 \mathrm{M} \mathrm{N}$-acetylglucosamine had no effect on the functional properties of the insulin receptor (Reference 18, and our data). Experimental groups were always compared to control insulin receptors prepared the same day from untreated animals.

Insulin specifically bound to receptors in the wheat germ eluate was linear between 12.5 and $75 \mu \mathrm{l}$ of the eluate assayed in a constant volume ( $r=0.97$ and 0.96 for control and diabetic receptor preparations, respectively). The ${ }^{32} \mathrm{P}$ incorporated into the $\beta$-subunit of the insulin receptor, after exposure to maximally stimulating insulin concentrations $\left(10^{-7}\right)$, was also linear bet ween 10 and $50 \mu \mathrm{l}$ of the wheat germ eluate, $(r=0.98$ and 0.97 for control and diabetic receptor preparations, respectively). These values were derived from three different pairs of receptor preparations (diabetic and control), with each point assayed in duplicate or triplicate.

Receptor autophosphorylation. $50 \mu \mathrm{l}$ of WGA eluate from control animals and appropriately diluted receptors from diabetic or insulintreated diabetic animals were incubated in $25 \mathrm{mM}$ Hepes, $\mathrm{pH} 7.4,0.1 \%$ Triton X-100, $5 \mathrm{mM} \mathrm{MnCl}, 0.05 \%$ bovine serum albumin (buffer A) with increasing insulin concentrations in $75 \mu \mathrm{l}$ of final volume for 45 $\min$ at $25^{\circ} \mathrm{C}$. The reaction mixtures were then cooled to $4^{\circ} \mathrm{C}$, and $[\gamma-$ $\left.{ }^{32} \mathrm{P}\right] \mathrm{ATP}(10 \mu \mathrm{l} \sim 15 \mu \mathrm{Ci}, 100 \mu \mathrm{M}$ final concentration) was then added, and after $30 \mathrm{~min}$ at $4^{\circ} \mathrm{C}$, the phosphorylation reaction was terminated by the addition of $28 \mu \mathrm{l}$ four-times concentrated Laemmli's sample buffer, heated at $100^{\circ} \mathrm{C}$ for $3 \mathrm{~min}$ and the proteins were separated by sodium dodecyl sulfate-polyacrylamide gel electrophoresis (SDS-PAGE) (see below). The $\beta$-subunit of the insulin receptor was localized by autoradiography, excized, and digested in $1 \mathrm{ml}$ of $30 \% \mathrm{H}_{2} \mathrm{O}_{2}$ at $60^{\circ} \mathrm{C}$ for $10 \mathrm{~h}$, and the ${ }^{32} \mathrm{P}$ content was determined by counting in $10 \mathrm{ml}$ of Scintiverse II (Fisher Scientific Co., Norcross, GA) in a Beckman LS7000 scintillation counter. Insulin degradation by the receptor preparation during incubation at $25^{\circ} \mathrm{C}$ in buffer A was estimated by TCA precipitability of added ${ }^{125}$ I-insulin tracer; $<2 \%$ of added insulin became TCA-soluble after $2 \mathrm{~h}$ of incubation.

Exogenous substrate kinase activity was determined using angiotensin II as the phosphoacceptor, as described by Rosen et al. (18). Approximately 10-20 fmol insulin-binding activity was incubated with or without insulin at $25^{\circ} \mathrm{C}$ for $1 \mathrm{~h}$ in $225 \mu \mathrm{l}$ of buffer $\mathrm{A}$. Autophosphorylation was initiated by the addition of $\left[\gamma-{ }^{32} \mathrm{P}\right] \mathrm{ATP}(50 \mu \mathrm{Ci}, 100 \mu \mathrm{M}$ final concentration) and allowed to proceed for $30 \mathrm{~min}$ at $4^{\circ} \mathrm{C}$. Aliquots $(35 \mu \mathrm{l})$ were then added to $5 \mu$ lof buffer $A$ or buffer $A$ containing $2 \mathrm{mM}$ angiotensin II and the phosphorylation was carried out at $4^{\circ} \mathrm{C}$ for $5 \mathrm{~min}$, which was in the linear part of the velocity curve as determined in preliminary experiments. The reaction was stopped by the addition of $5 \mu \mathrm{l}$ of $1.5 \%$ bovine serum albumin (BSA) and $50 \mu 1$ 5\% TCA. After centrifugation, 
duplicate $40-\mu \mathrm{l}$ aliquots were spotted onto phosphocellulose paper, washed, and counted as described (18).

Kinase activity of insulin receptors bound to insulin-agarose. Control receptors $(120 \mu \mathrm{l})$ and equal binding activity of diabetic-derived receptors were diluted to a final volume of $320 \mu$ l with buffer consisting of $50 \mathrm{mM}$ Hepes, $\mathrm{pH} 7.4,0.1 \%$ Triton X-100, $1 \mu \mathrm{g} / \mathrm{ml}$ leupeptin, and $2 \mathrm{mM}$ PMSF (buffer B); $50 \mu \mathrm{l}$ of insulin-agarose beads or agarose-beads inactivated with hot dithiothreitol (27) were added and the mixture incubated for 1 $\mathrm{h}$ at $25^{\circ} \mathrm{C}$. After centrifugation the pellet was washed twice with $1 \mathrm{ml}$ of buffer B supplemented with $0.5 \mathrm{M} \mathrm{NaCl}$ and then with buffer $\mathrm{B}$ alone. The pellet was then resuspended in $75 \mu$ l of $50 \mathrm{mM}$ Hepes, pH 7.4, 0.1\% Triton X-100, $0.025 \% \mathrm{BSA}$, and $5 \mathrm{mM} \mathrm{MnCl}_{2}$ (phosphorylation buffer) supplemented with $750 \mu \mathrm{M}$ ATP and incubated for $15 \mathrm{~min}$ at $25^{\circ} \mathrm{C}$ to induce maximal receptor autophosphorylation (27). The mixture was then diluted with $1 \mathrm{ml}$ of salt-supplemented buffer B, centrifuged, and the pellet washed with $1 \mathrm{ml}$ of buffer $B$, and was then resuspended in 75 $\mu$ of phosphorylation buffer, supplemented with $1 \mathrm{mg} / \mathrm{ml}$ histone $\mathrm{H}_{2} \mathrm{~b}$ and $50 \mu \mathrm{M}\left[\gamma_{-}{ }^{32} \mathrm{P}\right] \mathrm{ATP}(2.5 \mu \mathrm{Ci} /$ vial $)$ and incubated for $4 \mathrm{~min}$ at $25^{\circ} \mathrm{C}$. The reaction was stopped by the addition of hot four-times concentrated Laemmli's sample buffer and the sample was separated on SDS-PAGE and autoradiographed as described below. The bands corresponding to histone $\mathrm{H}_{2}$ b were excized and the ${ }^{32} \mathrm{P}$ was quantitated as described above for the insulin receptor $\beta$-subunit.

ATPase activity. Equal binding activities of control and diabetic derived wheat germ eluates were incubated as described for the autophosphorylation assays except that the specific activity of the ATP was decreased $(\sim 6 \mu \mathrm{Ci} / \mathrm{ml}$, ATP final concentration $10-100 \mu \mathrm{M})$. At various time intervals ( $30 \mathrm{~s}-120 \mathrm{~min})$ the reaction was stopped by the addition of $65 \mu \mathrm{l}$ of $3 \mathrm{M}$ perchloric acid, and after 5-min equilibration at $4^{\circ} \mathrm{C}$, $200 \mu \mathrm{l}$ of $\mathrm{dH}_{2} \mathrm{O}$ were added and the protein was removed by centrifugation. The supernatant $(300 \mu \mathrm{l})$ was neutralized with $60 \mu \mathrm{l} 2 \mathrm{M} \mathrm{KHCO}_{3}$, clarified by centrifugation, supplemented with $2 \mu \mathrm{l}$ of a $2 \mathrm{M}$ solution of unlabeled carrier ATP, and $20 \mu \mathrm{l}$ was analyzed on a Perkin-Elmer high performance liquid chromatograph (Perkin-Elmer Corp., Norwalk, CT) using a 5-cm $\mathrm{C}_{18}$ reverse-phase column. ATP was eluted isocratically in a buffer composed of $20 \mathrm{mM}$ phosphoric acid (pH to 6.5 with triethylamine, $98 \%$ ) and methanol (2\%) at a flow rate of $2 \mathrm{ml} / \mathrm{min}(28)$. The first $1.5 \mathrm{~min}$ of the run (containing inorganic phosphate) and the ATP peak were collected separately and ${ }^{32} \mathrm{P}$ counts per minute quantitated by liquid scintillation counting. These assays were performed in parallel with assays of insulin-receptor kinase activities. All kinase assays reported here were carried out under conditions where ATP degradation was $<10 \%$.

Cross-linkage of solubilized insulin receptors with ${ }^{125}$ I-insulin. Wheat germ eluates $(1 \mathrm{ml})$ from control and diabetic-derived muscle extracts were dialyzed against $25 \mathrm{mM}$ Hepes, $\mathrm{pH} 7.6$, and concentrated approximately fourfold with Aquacide (Calbiochem-Behring Corp.). Equal binding activities were incubated for $15 \mathrm{~h}$ at $4^{\circ} \mathrm{C}$ with $\mathrm{Al} 14^{125} \mathrm{I}$-insulin $(0.5 \mu \mathrm{Ci})$ with or without $10 \mu \mathrm{g} / \mathrm{ml}$ unlabeled insulin in $250 \mu \mathrm{l}$ of final volume, then disuccinimidyl suberate was added in dimethyl sulfoxide (DMSO) to a final concentration of $2 \mathrm{mM}$ at $4^{\circ} \mathrm{C}$, for $15 \mathrm{~min}$ (29). After addition of four-times concentrated Laemmli's sample buffer, the mixture was boiled for $3 \mathrm{~min}$. Electrophoresis and autoradiography were performed as described below.

Immunoprecipitation and partial proteolytic digestion of phosphorylated insulin receptors. WGA eluate was incubated in the presence of $10^{-7} \mathrm{M}$ insulin for $45 \mathrm{~min}$ at $25^{\circ} \mathrm{C}$ in buffer $\mathrm{A}(100 \mu \mathrm{l}$ of final volume) and $\left[\gamma{ }^{32} \mathrm{P}\right] \mathrm{ATP}(10 \mu \mathrm{M}, 10 \mu \mathrm{Ci})$ added for an additional $10 \mathrm{~min}$. The reaction was stopped by addition of $20 \mu \mathrm{l}$ of $40 \mathrm{mM}$ ATP, and $10 \mathrm{mM}$ $\mathrm{Na}_{4} \mathrm{PO}_{5}, 2 \mathrm{mM}$ PMSF, in buffer A. Antiinsulin receptor antibody (1: 400 dilution) was added and incubated overnight at $4^{\circ} \mathrm{C}$. Protein $\mathrm{A}$ bearing formalin-fixed $S$. aureus was added and incubated for an additional $2 \mathrm{~h}$ and the precipitated complex was washed three times with $25 \mathrm{mM}$ Hepes, $0.1 \%$ Triton X-100. Partial proteolytic digestion of the immune complex was achieved by resuspending it in $50 \mathrm{mM}$ sodium acetate buffer, pH $5(10 \mu \mathrm{l})$ containing $75 \mu \mathrm{g} / \mathrm{ml} \mathrm{V8}$ protease and incubating for $5 \mathrm{~min}$ at $37^{\circ} \mathrm{C}$. The reaction was stopped either by the addition of an equal volume twice-concentrated Laemmli's sample buffer or by the addition of $10 \mu \mathrm{l}$ of protease inhibitor cocktail (PIC) I and $5 \mu \mathrm{l}$ of PIC II (PIC I was composed of $1.5 \mathrm{mg} / \mathrm{ml}$ benzimidine, $1.5 \mathrm{mg} / \mathrm{ml}$ leupeptin, $1.5 \mathrm{mg} / \mathrm{ml}$ benzoyl arginine ethyl ester in $10 \mathrm{TIU} / \mathrm{ml}$ aprotinin; PIC II was composed of $1 \mathrm{mg} / \mathrm{ml}$ PMSF and $1 \mathrm{mg} / \mathrm{ml}$ antipain in DMSO). The protease-inhibited mixtures were then treated with glycosidases as described below.

Phosphoamino acid analysis. The phosphorylated, immunoprecipitated $\beta$-subunit was identified by autoradiography of the wet, unfixed gel after SDS-PAGE and solubilized by electroelution as follows: a 2 $\times 2$-cm gel slice was placed in a dialysis bag containing electrophoresis

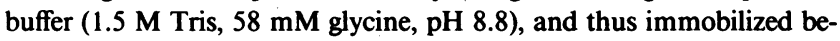
tween the glass plates of the vertical gel electrophoresis apparatus, was immersed in this buffer. One end of the sandwich was plugged with 15\% acrylamide and a potential of $500 \mathrm{~V}$ was applied for $1 \mathrm{~h}$. The contents of the bag were removed, $30 \mu \mathrm{g}$ of bovine $\gamma$-globulin was added and the protein was precipitated by making the solution $20 \%$ in TCA. The precipitate was dissolved in $250 \mu \mathrm{l}$ of $6 \mathrm{~N} \mathrm{HCl}$ and hydrolyzed at $110^{\circ} \mathrm{C}$ for 60 min under $\mathrm{N}_{2}$ atmosphere. The hydrolysate was adsorbed to $0.5 \mathrm{ml}$ of Dowex 1-X8, washed with $2 \mathrm{ml}$ of $\mathrm{dH}_{2} \mathrm{O}$ and eluted with $1 \mathrm{ml} 0.1 \mathrm{~N}$ $\mathrm{HCl}$ (30). The lyophilized sample was redissolved in $5 \mu \mathrm{l}$ of a mixed phosphoamino acid standard containing $0.33 \mathrm{mg} / \mathrm{ml}$ each of phosphoserine, phosphothreonine, and phosphotyrosine and spotted on thin cellulose TLC plates $(0.1 \mathrm{~mm}$ thick). The plates were electrophoresed at $1,000 \mathrm{~V}$ for $\mathbf{4 0} \mathrm{min}$ in pyridine/acetic acid/ $\mathrm{H}_{2} \mathrm{O}(5: 15: 945)$ towards the anode (30). The phosphoamino acids were localized by ninhydrin staining and by autoradiography at $-80^{\circ} \mathrm{C}$ with intensifying screen.

Tryptic phosphopeptide mapping. Electroeluted receptors were precipitated at $4^{\circ} \mathrm{C}$ in $10 \%$ TCA with $30 \mu \mathrm{g}$ of carrier bovine $\gamma$-globulin and the precipitate was extracted three times with $750 \mu$ l of $1: 1$ ether/ ethanol (31). The washed pellet was oxidized at $25^{\circ} \mathrm{C}$ for $2 \mathrm{~h}$ by the addition of $200 \mu \mathrm{l}$ of $9: 1$ formic acid/ $\mathrm{H}_{2} \mathrm{O}_{2}$, diluted to $2 \mathrm{ml}$ with water, and lyophilized. The lyophilizate was resuspended in $0.3 \mathrm{ml}$ of $50 \mathrm{mM}$ $\left(\mathrm{NH}_{4}\right)_{2} \mathrm{CO}_{3}, \mathrm{pH} 8.0$, containing $75 \mu \mathrm{g} / \mathrm{ml} \mathrm{L}$-1-tosylamide-phenylethy chloromethyl ketone (TPCK)-treated trypsin and incubated at $25^{\circ} \mathrm{C}$ for $12 \mathrm{~h}$ when an additional $40 \mu \mathrm{g}$ of trypsin was added and incubation was continued for another $12 \mathrm{~h}$. The mixture was brought to $3 \mathrm{ml}$ with water and lyophilized three times, resuspending in $3 \mathrm{ml}$ of water each time (31). Phosphopeptides were separated in two dimensions on $20 \mathrm{~cm}$ $\times 20 \mathrm{~cm} \times 0.1 \mathrm{~mm}$ TLC plates by electrophoresis in $1 \%$ ammonium bicarbonate, $\mathrm{pH} 8.9$, for $\mathbf{4 0}$ min towards the anode and then by ascending chromatography in pyridine/butanol/acetic acid/water (70:50:15:60) in the second dimension (32). Phosphopeptides were localized by autoradiography at $-80^{\circ} \mathrm{C}$ for $4 \mathrm{~h}$ with intensifying screens.

Treatment of immunoprecipitated receptors with endoglycosidase $H$. Washed, immunoprecipitated receptors with or without prior partial protease digestion were made $0.1 \%$ in SDS and heated for $1 \mathrm{~min}$ in boiling water. After cooling, $10 \mu \mathrm{l}$ of PIC I and $5 \mu \mathrm{l}$ of PIC II were added, followed by $50 \mu \mathrm{l}$ of $30 \mathrm{mU} / \mathrm{ml}$ endoglycosidase $\mathrm{H}$ in $50 \mathrm{mM}$ sodium acetate, $\mathrm{pH} 5.5,10 \mathrm{mM} \mathrm{CaCl}_{2}, 0.1 \%$ bovine serum albumin and incubated for $4 \mathrm{~h}$ at $37^{\circ} \mathrm{C}$. The samples were boiled in Laemmli's sample buffer (four-times concentrated) and separated on SDS-PAGE.

Neuraminidase. Immunoprecipitated receptors with or without prior partial V8 digestion were resuspended in $10 \mu \mathrm{l}$ of PIC I and $5 \mu \mathrm{l}$ of PIC II, followed by the addition of $40 \mathrm{mU} / \mathrm{ml}$ neuraminidase in $50 \mathrm{mM}$ sodium acetate, $\mathrm{pH} 5.0,10 \mathrm{mM} \mathrm{CaCl}_{2}$, and $150 \mathrm{mM} \mathrm{NaCl}$ and were incubated $4 \mathrm{~h}$ at $37^{\circ} \mathrm{C}$. As above the reaction was stopped by the addition of four-times concentrated Laemmli's sample buffer and proteins separated on SDS-PAGE. Methods for treatment of insulin receptors with glycosidases were modified from those described by Ronnett et al. (33).

Electrophoresis. SDS-PAGE was performed under reducing conditions using the discontinuous buffer system of Laemmli (34) with a 7.5\% polyacrylamide resolving gel for nonprotease-digested samples, a $9 \%$ polyacrylamide resolving gel for samples previously treated with V8 protease, and a linear $6-18 \%$ polyacrylamide resolving gel for reactions containing histone $\mathrm{H}_{2}$ b. A $4.5 \%$ polyacrylamide stacking gel was used for all samples. Samples were electrophoresed at $150-170 \mathrm{~V}$, constant voltage. Gels were stained, unless indicated, in 50\% methanol, $10 \%$ acetic acid, and $0.125 \%$ Coomassie blue $R$ and destained in $30 \%$ methanol and $10 \%$ 
acetic acid. The gels were dried in vacuo and autoradiography was performed with Kodak AR autoradiography film with or without Dupont Lightening + intensifying screens at $-80^{\circ} \mathrm{C}$.

\section{Results}

Animal condition. Rats rendered diabetic by i.p. injection of streptozotocin gained little or no weight during the subsequent $7 \mathrm{~d}$. Final weights of the diabetic rats were $111 \pm 4 \mathrm{~g}(n=23) \mathrm{vs}$. $164 \pm 4 \mathrm{~g}(n=15)$ for the controls. Insulin treatment $(60 \mathrm{~h})$ of diabetic rats resulted in rapid weight gain (final weight $145 \pm 5$ $\mathrm{g} ; n=10$ ). At the time of sacrifice the plasma glucose concentration of control rats was $130 \pm 4 \mathrm{mg} / \mathrm{dl}(n=15)$, that of untreated diabetic rats was $510 \pm 14 \mathrm{mg} / \mathrm{dl}(n=17)$, and that of insulin-treated diabetic rats was $94 \pm 6 \mathrm{mg} / \mathrm{dl}(n=12)$.

Insulin binding. Equilibrium binding of ${ }^{125} \mathrm{I}$-insulin by the partially purified insulin receptors extracted from hindlimb muscles of diabetic rats increased approximately twofold per milligram of protein in the wheat germ eluate as compared to controls (Fig. 1). When calculated per gram of muscle that increase in receptor number was 60-70\% $(\sim 100-125$ pmol insulin bound/g in control vs. $180-250 \mathrm{pmol}$ bound/g in the diabetic). Administration of insulin for $60 \mathrm{~h}$ caused a reduction in insulin receptor number per milligram of protein and per gram of tissue weight to nearly that of controls. The yield of milligrams of glycoprotein/gram of muscle from diabetic rats was $\sim 25 \%$ less than that obtained from controls, $0.55 \pm 0.06$ vs. $0.72 \pm 0.07$, re-

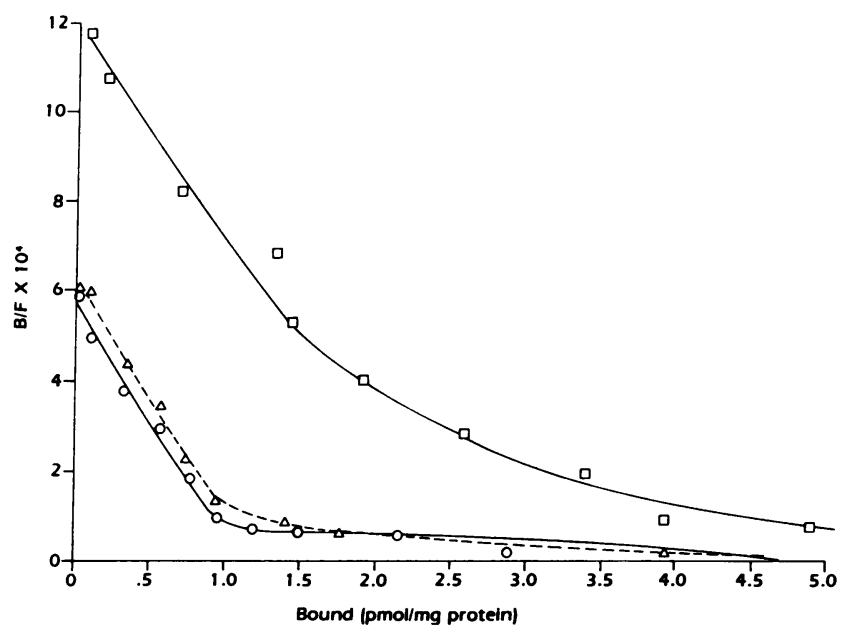

Figure 1. Scatchard analysis of ${ }^{125}$ I-insulin binding to solubilized, WGA-purified insulin receptors. WGA eluate $(50 \mu \mathrm{l})$ was incubated for $16 \mathrm{~h}$ at $4^{\circ} \mathrm{C}$ in a solution containing $25 \mathrm{mM}$ Hepes, $0.1 \%$ Triton $\mathrm{X}-100,150 \mathrm{mM} \mathrm{NaCl}, 0.1 \mathrm{mg} / \mathrm{ml}$ bovine serum albumin, and $100 \mathrm{U} /$ $\mathrm{ml}$ bacitracin with ${ }^{125} \mathrm{I}$-insulin $(10,000 \mathrm{cpm} ; 125-175 \mu \mathrm{Ci} / \mu \mathrm{g})$ and increasing concentrations of unlabeled insulin in a final volume of 200 $\mu \mathrm{l}$. The receptor and bound insulin were precipitated by sequential addition of $100 \mu \mathrm{l}$ of $0.3 \%$ bovine $\gamma$-globulin and $300 \mu \mathrm{l}$ of $25 \%$ polyethylene glycol. Nonspecific binding was estimated as the radioactivity precipitated in the presence of $10,000 \mathrm{ng} / \mathrm{ml}$ unlabeled insulin. Specific binding was normalized to protein concentration in the wheat germ eluate estimated by the Bradford reaction (26). Control (o), diabetic ( $\square$ ), and diabetic-treated $(\Delta)$ muscle-derived receptor population. Points are means of three to five determinations from two separate experiments. Standard error of the mean of picomoles bound per milligram of protein ranged from $7 \%$ to $17 \%$ of the mean. spectively ( $n=10 /$ group, $P<0.01$, paired analysis). The increase in receptor number solubilized from muscles of diabetic rats occurred without an apparent change in the affinity of the insulin receptor. These values were obtained after incubation at $4^{\circ} \mathrm{C}$ for $16 \mathrm{~h}$. Binding of ${ }^{125} \mathrm{I}$-insulin to control and diabetic-derived insulin receptors for $45 \mathrm{~min}$ at $25^{\circ} \mathrm{C}$ showed that $65-75 \%$ of equilibrium binding occurred in this time frame in both groups and the ratio of insulin bound by diabetic vs. control preparations was identical to that obtained with incubations for $15 \mathrm{~h}$ at $4^{\circ} \mathrm{C}$. Because the kinetics of insulin binding were identical in diabetic and control animals, the tyrosine kinase activity of the solubilized insulin receptors was routinely studied after $45 \mathrm{~min}$ to $1 \mathrm{~h}$ of incubation with insulin at $25^{\circ} \mathrm{C}$. Experiments performed after incubation with insulin for $16 \mathrm{~h}$ at $4^{\circ} \mathrm{C}$ yielded identical results to those shown below.

Insulin-stimulated autophosphorylation. Insulin stimulates the autophosphorylation of the insulin receptor through an intramolecular event $(20,35)$. As previously reported (23), when the WGA-purified insulin receptors from rat skeletal muscles were incubated with $\left[\gamma-{ }^{32} \mathrm{P}\right] \mathrm{ATP}, 5 \mathrm{mM} \mathrm{MnCl} \mathrm{M}_{2}$, and increasing concentrations of insulin, there was an insulin dose-dependent increase in the amount of ${ }^{32} \mathrm{P}$ incorporated into a $\sim 97,000-\mathrm{mol}$ wt peptide when the reaction mixture was analyzed by SDSPAGE and autoradiography. This peptide was identified as the $\beta$-subunit of the insulin receptor by its $\mathrm{MW}_{\text {app }}$, its ability to increase labeling after incubation with insulin, and its specific immunoprecipitability with antiinsulin receptor antibodies (see Reference 23).

When equal binding activities of control and diabetic-derived receptors were allowed to autophosphorylate at $4^{\circ} \mathrm{C}$ for $30 \mathrm{~min}$ in the presence of $100 \mu \mathrm{M}$ ATP, there was a significant decrease $(P<0.05)$ in the amount of ${ }^{32} \mathrm{P}$ incorporated into the $\beta$-subunit of the insulin receptor derived from diabetic animals incubated without insulin and at all insulin concentrations tested (Fig. 2). At maximally stimulating insulin concentrations, the mean autophosphorylation of control receptors was $40 \%$ greater than that of the diabetics; however, the insulin-stimulated autophosphorylation over base line ( $\Delta$ insulin) was only $20 \%$ greater in controls than in diabetics. Although the latter difference was not significant, as will be shown below, it resulted in marked impairment of insulin stimulated exogenous kinase activity. Halfmaximal activation of autophosphorylation occurred at $\sim 2$ $\times 10^{-9} \mathrm{M}$ insulin in controls and diabetics. When diabetic rats were treated with insulin to normalize their blood glucose levels, the insulin receptors derived from these animals showed nearly identical autophosphorylation kinetics as controls (Fig. 2).

Exogenous substrate kinase activity: The insulin receptor displays exogenous substrate tyrosyl kinase activity that is activated by the autophosphorylation event $(18,21)$. To investigate this property insulin receptors from control, diabetic, or diabetictreated animals were incubated for $1 \mathrm{~h}$ at $25^{\circ} \mathrm{C}$ with the indicated concentrations of insulin and then allowed to autophosphorylate in the presence of $100 \mu \mathrm{M}\left[\gamma_{-}{ }^{32} \mathrm{P}\right] \mathrm{ATP}$ at $4^{\circ} \mathrm{C}$ for $30 \mathrm{~min}$; exogenous kinase activity was then assessed for $5 \mathrm{~min}$ at $4^{\circ} \mathrm{C}$ using angiotensin II as the phosphoacceptor. Little exogenous kinase activity was observed in any of the groups in the absence of added insulin. At $10^{-9}$ and $10^{-7} \mathrm{M}$ insulin, a significant decrease in the exogenous substrate kinase activity was seen in the diabetic-derived receptors $(P<0.01$, Fig. 3$)$. The ability of insulin to stimulate the exogenous kinase activity over basal was significantly less in diabetic-derived receptors than in controls $(P$ $<0.01)$. Treatment of diabetic rats with insulin restored the 


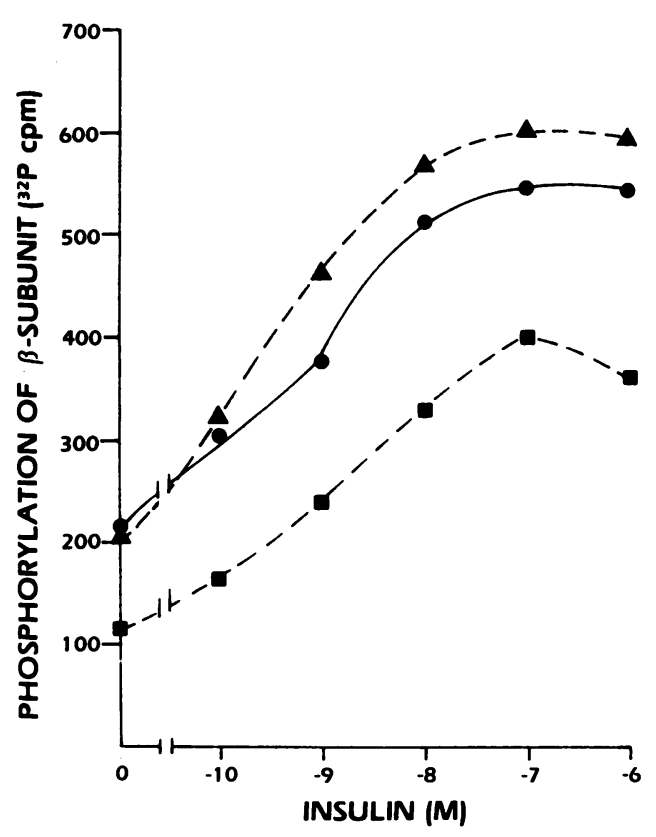

Figure 2. Dose-response of insulin-stimulated autophosphorylation of the $\beta$-subunit of solubilized insulin receptors. Wheat germ eluate (50$70 \mu$ l) from control-derived receptor $(\bullet)$ and equal binding activities from diabetic $(\square)$ and insulin-treated diabetic rats $(\Delta)$ were incubated for $45 \mathrm{~min}$ in $25 \mathrm{mM}$ Hepes, pH 7.4, 0.1\% Triton X-100, 0.05\% bovine serum albumin, $0.15-0.3 \mathrm{M} \mathrm{N}$-actylglucosamine, and $5 \mathrm{mM}$ $\mathrm{MnCl}_{2}$ at $25^{\circ} \mathrm{C}$ without or in the presence of $10^{-10}$ to $10^{-6} \mathrm{M}$ insulin in a final volume of $75 \mu \mathrm{l}$. After cooling the vials to $4^{\circ} \mathrm{C}$, autophosphorylation was initiated by the addition of $\left[\gamma_{-}{ }^{32} \mathrm{P}\right] \mathrm{ATP}(100 \mu \mathrm{M}, 15$ $\mu \mathrm{Ci} /$ vial) and the reaction continued for $30 \mathrm{~min}$ at $4^{\circ} \mathrm{C}$ and terminated by the addition of four-times concentrated Laemmli's sample buffer containing $5 \mathrm{mM}$ 2-mercaptoethanol and heated for $3 \mathrm{~min}$ at $100^{\circ} \mathrm{C}$. The samples were analyzed by $7.5 \%$ SDS-PAGE; the $\beta$-subunit was localized by autoradiography, excised, digested in $1 \mathrm{ml}$ of $30 \%$ $\mathrm{H}_{2} \mathrm{O}_{2}$, and counted in a liquid scintillation counter. Values are means for five separate preparations from control and diabetic rats, respectively, and three insulin-treated diabetics; preparations were assayed in triplicate in each group. All points in the diabetic-derived preparation are different from control, $P<0.05$; standard errors of the mean are $7 \%-12 \%$ of the means.

exogenous substrate kinase activity of the receptors toward normal (Fig. 3).

The decreased ability of diabetic-derived receptors to phosphorylate exogenous substrates was not temperature-dependent nor substrate-specific, in that similar decreases in the diabeticderived receptor kinase activity were observed at $25^{\circ} \mathrm{C}$ using histone $\mathrm{H}_{2} \mathrm{~b}$ as the phosphoacceptor. In these experimen is the wheat germ eluates were preincubated with insulin coupled to agarose, the agarose-bound receptors were extensively washed, and then allowed to fully autophosphorylate in the presence of $750 \mu \mathrm{M}$ ATP. The exogenous kinase activity was then assessed using $50 \mu \mathrm{M}\left[\gamma-{ }^{32} \mathrm{P}\right] \mathrm{ATP}$. When equal insulin-binding activities derived from control and diabetic muscles were incubated with the beads, there was again a significant decrease in the amount of label incorporated into the histone by the diabetic-derived receptors as compared to the controls (Fig. 4). When receptors were bound to insulin-agarose beads that had been inactivated with hot dithiothreitol (27), histone- $\mathrm{H}_{2} \mathrm{~b}$ phosphorylation was $\sim 10 \%$ of that observed with fully activated agarose-bound receptors (data not shown).

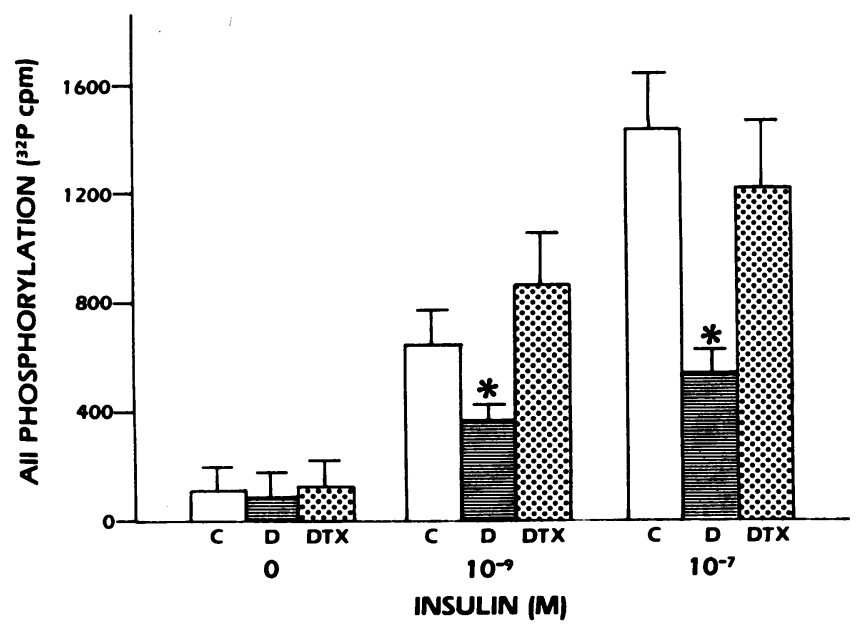

Figure 3. Angiotensin II phosphorylation by skeletal muscle-derived insulin receptors. WGA eluates were preincubated with $0,10^{-9}$, or $10^{-7} \mathrm{M}$ insulin for $45 \mathrm{~min}$ at $25^{\circ} \mathrm{C}$ and then allowed to autophosphorylate for $30 \mathrm{~min}$ at $4^{\circ} \mathrm{C}$ in the presence of $100 \mu \mathrm{M}\left[\gamma{ }^{32} \mathrm{P}\right] \mathrm{ATP}$. Aliquots $(35 \mu \mathrm{l})$ were added to $5 \mu \mathrm{l}$ of buffer or angiotensin II $(2 \mathrm{mM}$ final concn.) and the reaction continued for an additional $5 \mathrm{~min}$ when $50 \mu \mathrm{l}$ of $5 \%$ TCA was added. After cooling on ice for $30 \mathrm{~min}$, the protein precipitate was removed by centrifugation and duplicate $40-\mu \mathrm{l}$ aliquots were spotted onto phosphocellulose paper. After washing, the papers were counted in a liquid scintillation counter. Equal binding activities were assayed in each preparation. C, control; D, diabetic; DTX, diabetic-treated. Means \pm SEM for three to five different receptor preparations are shown, each assayed in triplicate. *, significantly different from control, $P<0.05$.

A number of mechanisms may explain the decreased kinase activity of the diabetic-derived receptor population, including errors in the estimation of insulin receptor number or contaminants in the wheat germ eluate altering insulin receptor phosphorylation. Insulin that was "carried over" in the preparation of the insulin receptor could lead to an underestimate of the true insulin receptor number, especially in the control-derived preparations. This possibility was examined by the addition of ${ }^{125}$ I-insulin to the muscle homogenate and by observing its recovery during different stages of purification. We found that $\leq 0.1 \%$ of the added radioactivity was recovered in the final wheat germ eluate and that this was entirely nonspecific binding in that an identical homogenate which was supplemented with $\mathbf{5 0}$ $\mu \mathrm{g} / \mathrm{ml}$ unlabeled insulin showed identical recovery of ${ }^{125} \mathrm{I}$-insulin. A second approach was to dialyze the insulin receptors exhaustively in the wheat germ eluate to remove insulin. Upon rebinding, identical ratios of estimated insulin receptor numbers from control and diabetic animals were obtained as those before dialysis. Furthermore, no change in basal or insulin-stimulated autophosphorylation was observed in the dialyzed receptors.

The alterations in insulin receptor kinase activities did not appear to be due to contaminating insulinases in the diabeticderived receptors nor to contaminating phosphatases because $<2 \%$ of added ${ }^{125}$ I-insulin was degraded by the WGA eluates over a 2 -h period and no change in the amount of ${ }^{32} \mathrm{P}$ associated with the insulin receptor $\beta$-subunit or with angiotensin II or histone $\mathbf{H}_{2}$ b was seen for 30 min after the addition of unlabeled ATP to previously phosphorylated insulin receptors and kinase substrates in either the control or diabetic derived preparations (data not shown). Although significant ATPase activity was de- 


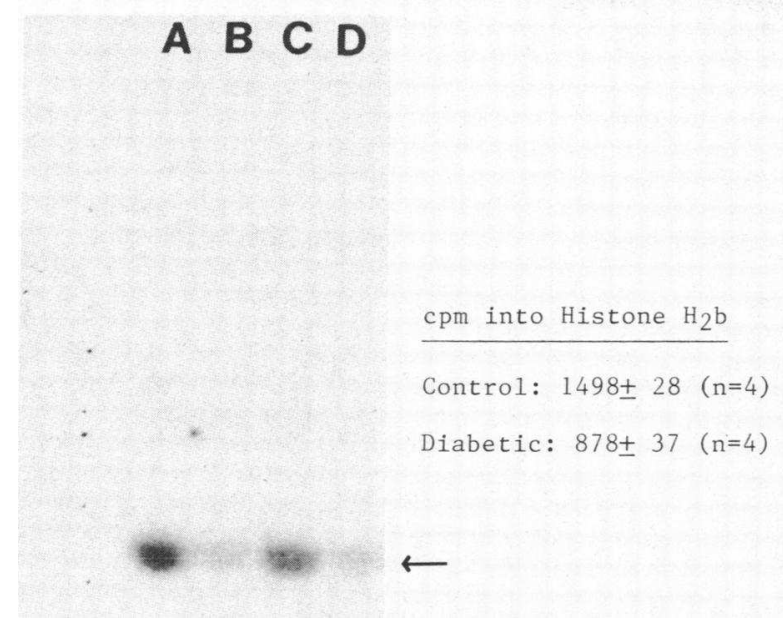

Figure 4. Autoradiogram of histone $\mathrm{H}_{2} \mathrm{~b}$ phosphorylated by skeletal muscle-derived insulin receptors. Wheat germ eluates of $120 \mu \mathrm{l}$ from controls and equal binding activity from diabetics were incubated with insulin-agarose conjugates for $60 \mathrm{~min}$ at $25^{\circ} \mathrm{C}$ as described in Methods. After washing, the insulin-agarose bound receptors were allowed to autophosphorylate in the presence of $750 \mu \mathrm{M} \mathrm{ATP,} 5 \mathrm{mM} \mathrm{MnCl}$, and $0.025 \% \mathrm{BSA}$ for $10 \mathrm{~min}$ at $25^{\circ} \mathrm{C}$, and then washed and incubated in phosphorylation buffer with $1 \mathrm{mg} / \mathrm{ml}$ of histone $\mathrm{H}_{2} \mathrm{~b}$ and $50 \mu \mathrm{M}[\gamma-$ $\left.{ }^{32} \mathrm{P}\right] \mathrm{ATP}(2.5 \mu \mathrm{Ci} /$ vial $)$ at $25^{\circ} \mathrm{C}$ for $4 \mathrm{~min}$. The reaction was stopped by the addition of four-times concentrated Laemmli's sample buffer and the samples were separated by SDS-PAGE and autoradiographed. Histone bands were excised, digested, and counted as described for the $\beta$-subunit in Fig. 2. Two separate sets of control and diabetic-derived receptors are shown. Lanes $A$ and $C, \mathbf{H}_{2}$ b phosphorylated by control receptors; lanes $B$ and $D, \mathrm{H}_{2}$ b phosphorylated by diabetic-derived receptors. Arrow indicates the position of $\mathrm{H}_{2} \mathrm{~b}$. (Inset) Mean $\pm \mathrm{SEM}$ of counts per minute of ${ }^{32} \mathrm{P}$ incorporated into histone $\mathrm{H}_{2} \mathrm{~b}$ from four different control and four diabetic-derived insulin receptor preparations (all with equal binding activity) each assayed in triplicate.

tected in the wheat germ eluates under some conditions, the results shown here were derived from assays, where $<10 \%$ of $\left[\gamma-{ }^{32} \mathrm{P}\right]$ ATP was degraded.

Fig. 5 shows the phosphoamino acid analysis of control and diabetic-derived insulin receptor $\beta$-subunits that were maximally stimulated by insulin and then exposed to $10 \mu \mathrm{M}\left[\gamma-{ }^{32} \mathrm{P}\right] \mathrm{ATP}$ for $10 \mathrm{~min}$ at $25^{\circ} \mathrm{C}$. As with other insulin receptors phosphorylated in vitro $(18,19)$, labeling occurred predominantly on tyrosine residues in both groups. Although a small amount of serine phosphorylation was observed, it contributed little to the total amount of phosphoamino acid present in either group.

Two dimensional phosphopeptide maps generated from tryspin digestion of the $\beta$-subunit of the insulin receptors derived from control and diabetic animals and autophosphorylated at $25^{\circ} \mathrm{C}$ are shown in Fig. 6. Although slight variations occur in the relative labeling of the various phosphopeptides generated by this procedure, no consistent changes occurred in a number of maps analyzed, thus we found no indication that a site or sites are eliminated from the diabetic-derived population that would account for the decrease in overall labeling.

Structure of the insulin receptor subunits. Incubation of wheat germ eluates from control and diabetic animals with A14 ${ }^{125} \mathrm{I}$ insulin with subsequent addition of disuccinimidyl suberate specifically labeled a protein of $\mathrm{MW}_{\text {app }} 131,000$ (Fig. 7), which corresponds to the approximate molecular weight of the $\alpha$-sub-

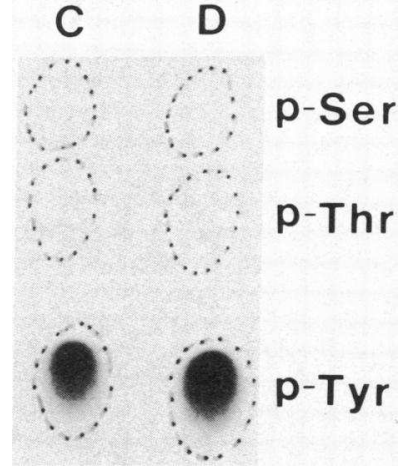

Figure 5. Phosphoaminoacid analysis of the $\beta$-subunit of skeletal muscle insulin receptors. Wheat germ-purified insulin receptors from control and diabetic animals were incubated with $10^{-7} \mathrm{M}$ insulin as described in Fig. 2. [ $\gamma^{32}$ P]ATP $(25 \mu \mathrm{M}, 10 \mu \mathrm{Ci} / v i a l)$ was added for $10 \mathrm{~min}$ at $25^{\circ} \mathrm{C}$ and the reaction was stopped with $20 \mu \mathrm{l}$ of $25 \mathrm{mM}$ Hepes, $0.1 \%$ Triton, $40 \mathrm{mM}$ ATP, $10 \mathrm{mM}$ sodium pyrophosphate, and $2 \mathrm{mM}$ PMSF, then antiinsulin receptor antibodies (1:400 dilution) were added and samples were incubated overnight at $4^{\circ} \mathrm{C}$. The immune complex was precipitated by the addition of Pansorbin, washed three times, and boiled in Laemmli's sample buffer. The phosphorylated $\beta$ subunit was eluted from the wet, unfixed gel as described in Methods, precipitated with $20 \% \mathrm{TCA}$, and hydrolyzed for $1 \mathrm{~h}$ at $110^{\circ} \mathrm{C}$ in $6 \mathrm{~N}$ $\mathrm{HCl}$. The hydrolysate was adsorbed to Dowex 1-X8; the phosphoaminoacids were eluted with $0.25 \mathrm{~N} \mathrm{HCl}$ and lyophilized. After addition of mixed phosphoaminoacid standards, the mixture was spotted on a TLC plate and electrophoresed for $45 \mathrm{~min}$ in pyridine/acetic acid/ $\mathrm{H}_{2} \mathrm{O}$ (5:15:950) pH 3.5. The phosphoaminoacid standards were localized by ninhydrin and ${ }^{32} \mathrm{P}$ by autoradiography. The autoradiogram presented shows control-derived receptors $(C)$ and diabetic-derived receptors $(D)$. The interrupted lines indicate the location of phosphoserine ( $p$ $S e r)$, phosphothreonine ( $p-T h r)$, and phosphotyrosine ( $p-T y r)$ standards. A small amount of phosphoserine was detected on the autoradiogram but did not reproduce on the photograph.

unit of the insulin receptor. No differences were observed in the electrophoretic migration of the insulin cross-linked $\alpha$-subunit between control and diabetic-derived insulin receptor populations. Furthermore, the amount of label bound per receptor was identical when diabetic- and control-derived wheat germ eluates were cross-linked with ${ }^{125}$ I-insulin.

In exploiting the property of autophosphorylation to localize the $\beta$-subunit of the insulin receptor, we investigated the possibility that the functional alterations observed in the insulin receptor from diabetic animals could stem from an identifiable structural alteration in this subunit. Insulin receptors were phosphorylated, immunoprecipitated, and separated under reducing conditions by SDS-PAGE. Autoradiography revealed that the $\beta$-subunit of the insulin receptor derived from diabetic animals included a component that showed a small but reproducible slowing in electrophoretic migration as compared to controls (Fig. 8, lanes $A$ and $B$ ). This change in electrophoretic migration became more prominent after short proteolytic digestion of the phosphorylated, immunoprecipitated receptor with V8 protease (Fig. 8, lanes $C$ and $D$ ). V8 protease treatment reproducibly generated two to four major phosphorylated species each of which showed this altered migration when derived from diabetic muscle.

The major phosphorylated peptides seen after V-8 digestion were shown to be derived from the $\beta$-subunit (as opposed to the variably phosphorylated $\alpha$-subunit) in the following manner. Phosphorylated, immunoprecipitated insulin receptors were electrophoresed under reducing conditions and the unstained, unfixed gel autoradiographed at $4^{\circ} \mathrm{C}$. The $\beta$-subunit was localized and excised, the gel slice placed in a dialysis bag and the phosphoprotein eluted as described in "Methods." The dialyzed, ly- 


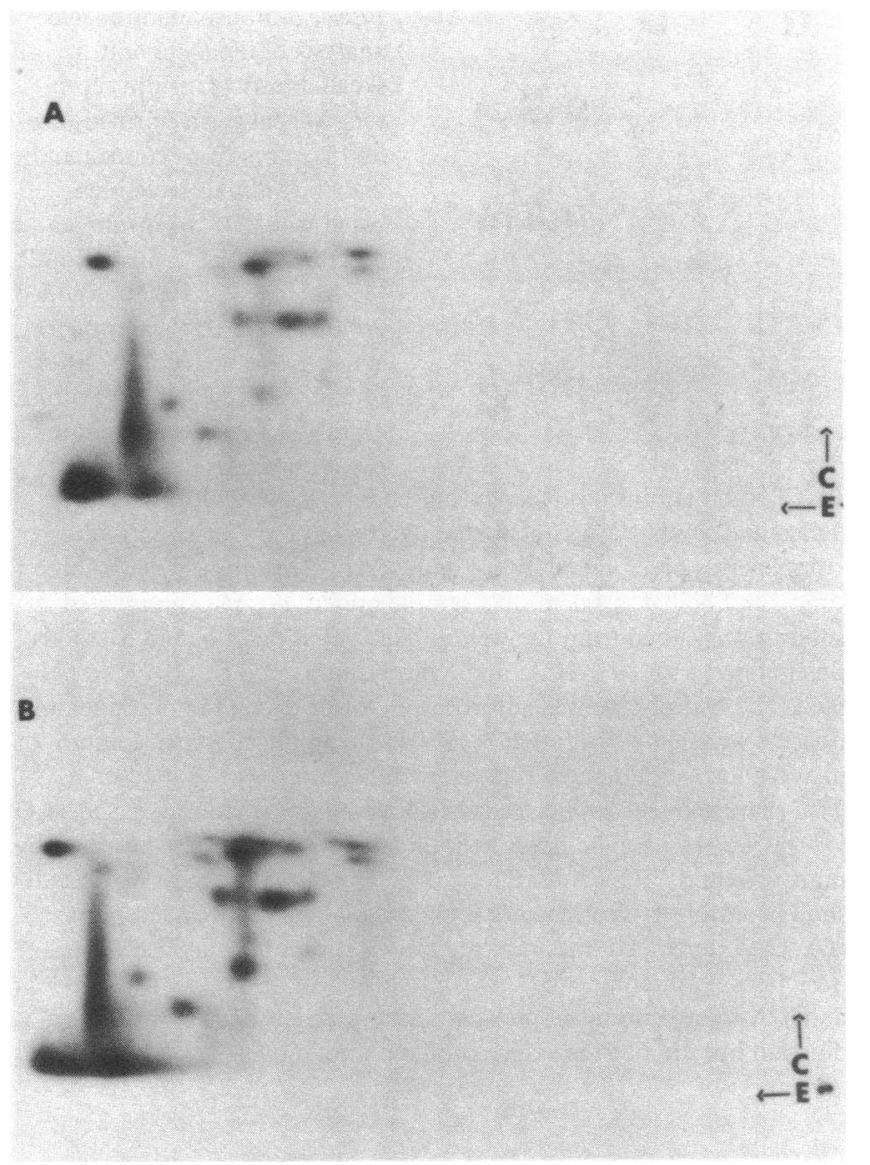

Figure 6. Two-dimensional phosphopeptide analysis and autoradiography of insulin receptor $\beta$-subunit. Insulin receptors from control $(A)$ and diabetic $(B)$ animals were phosphorylated, immunoprecipitated, eluted, and TCA-precipitated as described in Fig. 5. The precipitated protein was washed with ether/ethanol (1:1), oxidized with formic acid/ $\mathrm{H}_{2} \mathrm{O}_{2}$ (9:1), and digested with TPCK-treated trypsin in $50 \mathrm{mM}$ $\left(\mathrm{NH}_{4}\right)_{2} \mathrm{CO}_{3}, \mathrm{pH} 8$, for $24 \mathrm{~h}$. After removal of $\left(\mathrm{NH}_{4}\right)_{3}$ by lyophilization the hydrolysate was spotted on $20 \times 20$-cm TLC plates, electrophoresed for $40 \mathrm{~min}$ in the first dimension in $1 \%\left(\mathrm{NH}_{4}\right)_{2} \mathrm{CO}_{3}, \mathrm{pH} 8.9$, and ascended chromatographically in the second dimension with $N$-butanol/pyridine/acetic acid/ $\mathrm{H}_{2} \mathrm{O}(30: 15: 7: 37.5)$. The dried plate was then autoradiographed for $4 \mathrm{~d}$ at $-80^{\circ} \mathrm{C}$ with intensifying screens.

ophilized protein was then subjected to partial V8 digestion, equal numbers of counts from each treatment group $(\sim 4,000$ $\mathrm{cpm}$ ) were loaded in each lane and reelectrophoresed. The autoradiograph, (Fig. 8, lanes $F$ and $G$ ) shows the same major phosphorylated species as were generated by partial digestion of the immunoprecipitated intact receptor (lanes $C$ and $D$ ) with the fragments generated from diabetic-derived $\beta$-subunits again showing a component with retarded mobility when compared to controls.

As shown in Fig. 8, lanes $E$ and $H$, the diabetes-associated alteration in electrophoretic mobility was reversed by $60 \mathrm{~h}$ of in vivo insulin treatment that normalized blood sugar. Lanes $I$ and $J$ show autoradiograms of control- and diabetic-derived insulin receptors that were immunoprecipitated and partially digested with V-8 protease. Brief autoradiography revealed the diabetic derived $\beta$-subunit (lane $J$ ) to consist of two distinct populations, one that comigrates with the control receptor (lane $I$ ) and one with retarded migration.

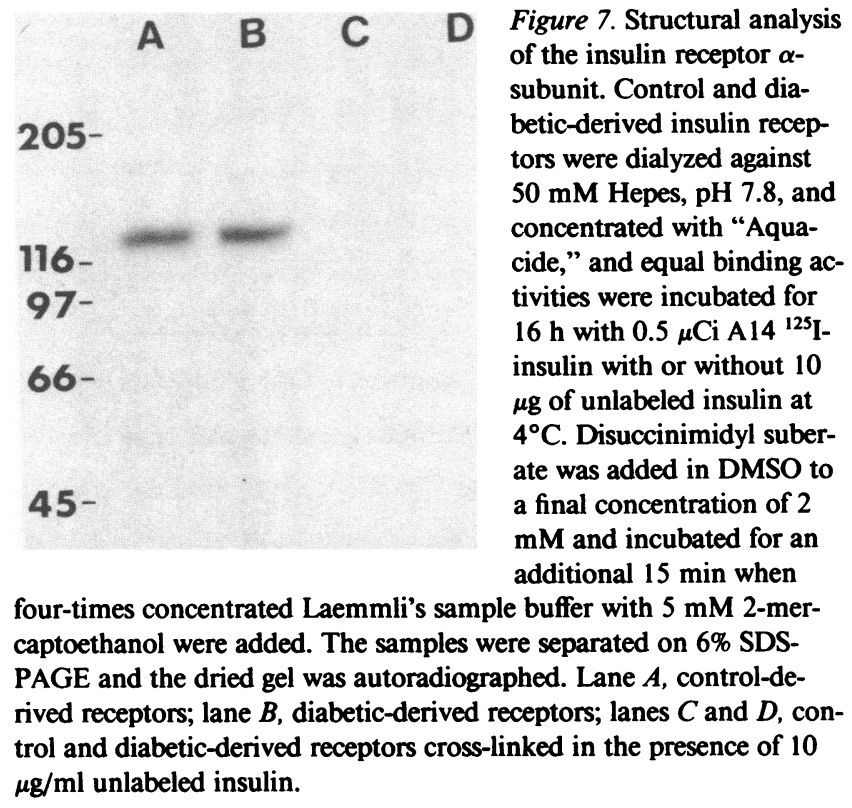

We next investigated the possibility that sugar side chains associated with this glycopeptide could be altered in the diabetic state. Considering the difficulty in metabolically labeling the

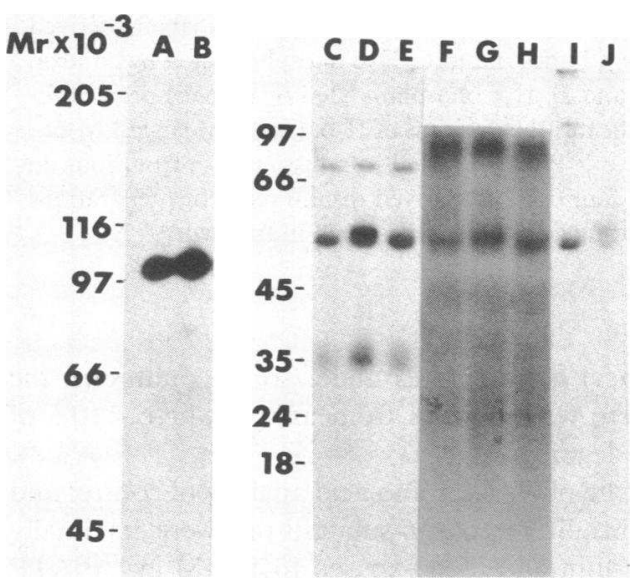

Figure 8. Structural analysis of insulin receptor $\beta$-subunit. Wheat germ eluates with approximately equal insulin binding activities, prepared from muscles of control, diabetic, and diabetic-treated rats were incubated with $10^{-7} \mathrm{M}$ insulin for $45 \mathrm{~min}$ and autophosphorylated for $10 \mathrm{~min}$ in the presence of $10 \mu \mathrm{M}\left[\gamma^{32} \mathrm{P}\right] \mathrm{ATP},(\sim 15 \mu \mathrm{Ci} / 100 \mu \mathrm{l})$. Receptors were immunoprecipitated with antiinsulin receptor antibody and Pansorbin. The precipitates were either boiled in Laemmli's sample buffer and analyzed by $7.5 \%$ SDS-PAGE under reducing conditions or first digested for $5 \mathrm{~min}$ at $37^{\circ} \mathrm{C}$ in $50 \mathrm{mM}$ sodium acetate buffer, pH 5 , with $75 \mu \mathrm{g} / \mathrm{ml} S$. aureus $\mathrm{V} 8$ protease and then analyzed by $9 \%$ SDS-PAGE under reducing conditions. Dried, fixed gels were autoradiographed with intensifying screens at $-80^{\circ} \mathrm{C}$ for $12-24 \mathrm{~h}$. Lane $A$, control; lane $B$, diabetic-derived receptors without protease digestion. Lanes $C, D$, and $E$, receptors derived from control, diabetic, and insulin-treated diabetic rats, respectively, with prior $\mathrm{V} 8$ protease, digestion. Lanes $F, G$, and $H, \beta$-subunits from control, diabetic, and diabetic-treated, respectively, that were isolated from a $7.5 \%$ gel by electroelution and subsequently digested with V8 as described in the text. Lane $I$, control; lane $J$, diabetic-derived receptors after $\mathrm{V} 8$ protease digestion, and short autoradiographic exposure. 
sugar side chains and the minute amounts of insulin receptors available for chemical modification, we used enzymatic digestion of the insulin receptor with glycosidases in an attempt to characterize the structure of the glycosyl residues. Incubation of the immunoprecipitated insulin receptor with endoglycosidase $\mathbf{H}$ caused an $\sim 5,000$ decrease in $\mathrm{MW}_{\text {app }}$ in control- and diabeticderived insulin receptors (Fig. $9 a$, lanes $A, B$ and $E, F$ ) but did not correct (and actually accentuated) the difference between the control and diabetic. Endoglycosidase $\mathrm{H}$ digestion of the immunoprecipitated receptor after partial V8 proteolysis was accomplished by adding an excess of protease inhibitors before the addition of the endoglycosidase. Again a decrease in $\mathbf{M W}_{\text {app }}$ of $\sim 4,000-5,000$ occurred in the major phosphopeptides generated from control- and diabetic-derived $\beta$-subunits and allowed the separation of the diabetic derived receptors into two distinct populations (Fig. $9 b$, lanes $E$ and $F$ ), one that comigrates with the control, and one with retarded electrophoretic migration. The decrease in $\mathbf{M W}_{\text {app }}$ of the $\beta$-subunit after endoglycosidase $\mathrm{H}$ treatment suggested that this glycoprotein contains "high mannose" sugar side chains.

Neuraminidase is an exoglycosidase that removes terminal sialic acid residues from the sugar side chains of glycoproteins. When the immunoprecipitated insulin receptor was digested with this enzyme, a decrease in $\mathrm{MW}_{\text {app }}$ of $\sim 2,000$ occurred in control lanes (Fig. $9 a$, lanes $A$ and $C$ ). A similar decrease occurred in the diabetic-derived insulin receptor (Fig. $9 a$, lanes $B$ and $D$ ); in addition, there was an apparent normalization in the electrophoretic migration of this population as compared to control (Fig. $9 a$, lanes $C$ and $D$ ). Neuraminidase treatment caused a slight decrease in $\mathrm{MW}_{\text {app }}$ of the major $(\sim 54,000)$ phosphorylated peptide in the diabetic-derived population (Fig. $9 b$, lanes $B$ and $D$ ), and nearly normalized the migration of the diabetic-derived phosphopeptides as compared to control (Fig. $9 b$, lanes $C$ and $D$ ).

However, double glycosidase digestion, i.e., neuraminidase followed by endoglycosidase $\mathrm{H}$, showed that the second, slower migrating band in the diabetic-derived preparation increased its electrophoretic migration but was not completely eliminated after neuraminidase treatment (Fig. 10, demonstrating the main $\sim 54,000 \mathrm{MW}_{\text {app }}$ phosphopeptide generated by V8 protease digestion). This result raises the possibility that an additional component, possibly "core" sugars, may contribute to the heterogeneity in electrophoretic migration of the diabetic-derived $\beta$-subunit.

\section{Discussion}

An increase in the number of insulin receptors associated with insulinopenia has been observed in adipocytes $(9,10)$, and hepatocytes $(13,36)$. In the present study the number of insulin receptors solubilized per gram of hindlimb muscle was increased $60-70 \%$ after $7 \mathrm{~d}$ of diabetes, without an apparent change in affinity. Insulinopenic diabetes in rats has been reported to cause no change $(10,36)$ or to increase the affinity of insulin receptors $(10,37)$ in adipocytes and liver. Studies of insulin binding to intact, incubated soleus muscles from streptozotocin diabetic mice reported findings of increased binding affinity without a change in receptor number (38). These discrepancies may reflect the difficulty in interpreting changes in insulin binding kinetics, especially when intact tissues are used, as well as possible differences between solubilized, total receptors assessed in the present study versus surface receptors on intact muscle cells studied

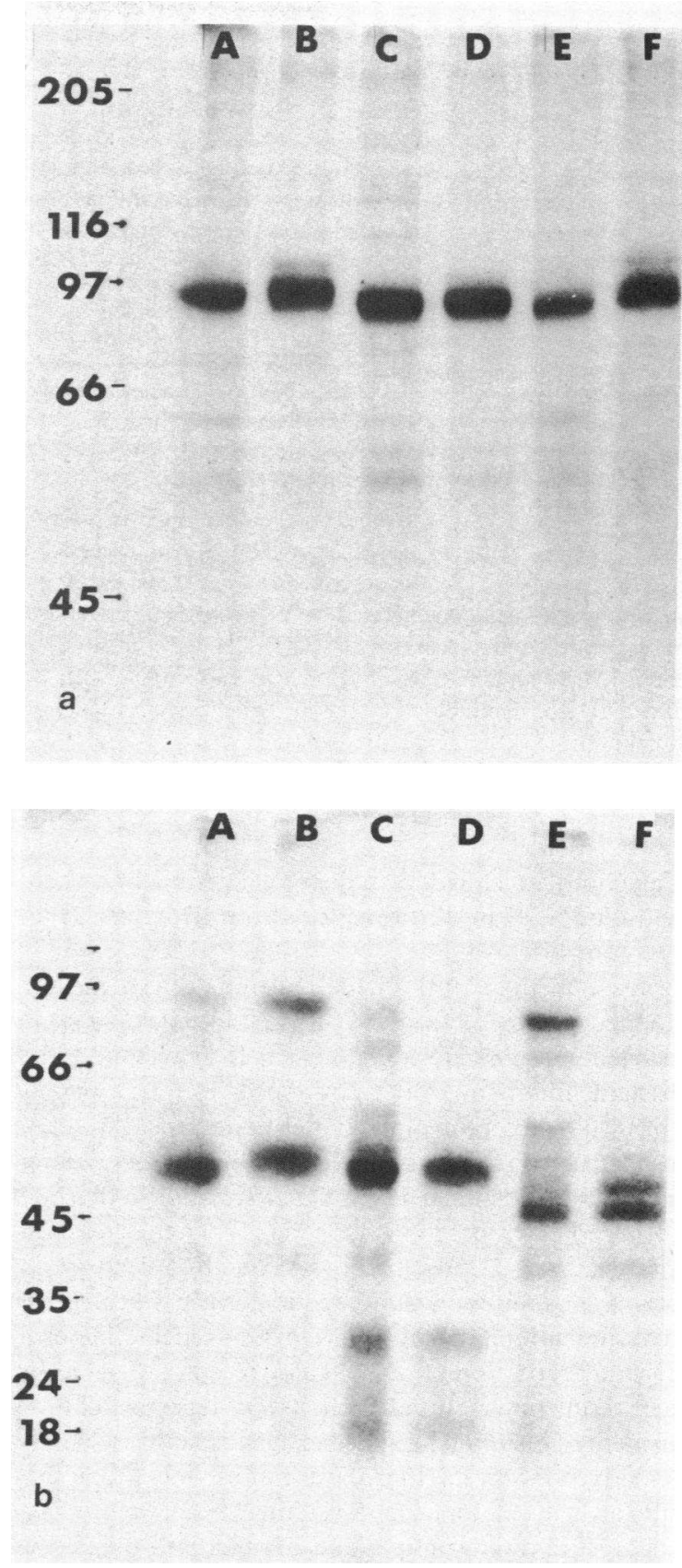

Figure 9. Glycosidase digestion of phosphorylated, immunoprecipitated insulin receptors. Autophosphorylated insulin receptors were immunoprecipitated and incubated for 5 min without $(a)$ or with $(b)$ V8 protease as described in Fig. 8. After addition of protease inhibitors, samples were incubated with buffer alone (lanes $A$ and $B$ ) or with neuraminidase $(40 \mathrm{mU} / \mathrm{ml}$, lanes $C$ and $D)$ or with endoglycosidase $\mathrm{H}$ $\left(30 \mathrm{mU} / \mathrm{ml}\right.$, lanes $E$ and $F$ ) at $37^{\circ} \mathrm{C}$ for $4 \mathrm{~h}$ as detailed in Methods after which four-time concentrated Laemmli's sample buffer was added, the samples analyzed by SDS-PAGE and autoradiographed. Lanes $A, C$, and $E$, control-derived receptors; lanes $B, D$, and $F$, diabetic-derived receptors. The numbers on the left indicate the positions of molecular weight markers in thousands.

in Reference 38. It should be noted that the increased number of receptors observed in muscles after $7 \mathrm{~d}$ of diabetes in this report reflects in part differences in growth rate and muscle weight between control and diabetic rats and the $\sim 25 \%$ decrease in the 


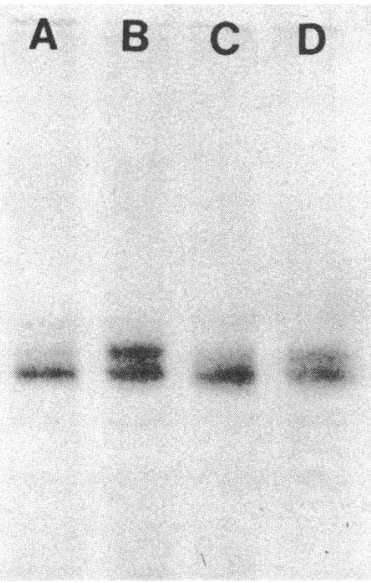

Figure 10. Sequential neuraminidase and endoglycosidase $\mathrm{H}$ treatment of V8-digested insulin receptors. Insulin receptors were immunoprecipitated and digested with V8 protease as described in Fig. 8. After addition of protease inhibitors and incubation with $40 \mathrm{mU} /$ $\mathrm{ml}$ neuraminidase for $2 \mathrm{~h}$ at $37^{\circ} \mathrm{C}$ samples were placed in boiling water for $2 \mathrm{~min}$. After cooling, endoglycosidase $\mathbf{H}$ (final concentration $30 \mathrm{mU} / \mathrm{ml}$ ) was added in fourtimes concentrated endoglycosidase $\mathrm{H}$ buffer $(1 / 3 \mathrm{vol})$, and the sample was incubated for an additional $2 \mathrm{~h}$ at $37^{\circ} \mathrm{C}$, then processed as described in Fig. 9. The major

$\left(\mathrm{MW}_{\mathrm{app}} 54,000\right)$ phosphopeptide generated by $\mathrm{V} 8$ protease digestion is shown. Lane $A$, control, endoglycosidase $\mathrm{H}$-treated; lane $B$, diabetic, endoglycosidase $\mathrm{H}$-treated; lane $C$, control, treated sequentially with neuraminidase and endoglycosidase $\mathrm{H}$; lane $D$, diabetic, sequentially treated with neuraminidase and endoglycosidase $\mathrm{H}$.

amount of glycoprotein eluted from the wheat germ affinity column in the isolation of insulin receptors from diabetic rats as compared to controls.

The decrease in the ability of the diabetic-derived insulin receptors to incorporate ${ }^{32} \mathrm{P}$ from $\left[\gamma-{ }^{32} \mathrm{P}\right] \mathrm{ATP}$ into its $\beta$-subunit and into exogenous substrates (angiotensin II or histone $\mathbf{H}_{2}$ b) was a consistent finding and does not appear to reflect biased estimates of insulin receptor number nor contaminating insulinase, phosphatase, or ATPase activities. Note that cross-linking experiments revealed identical labeling of $\alpha$-subunits in diabetic and control receptor preparations (see Fig. 7). The decrease in autophosphorylation was presumably not due to a decrease in the number of $\beta$-subunits in the diabetic-derived wheat germ eluate in that similar binding kinetics were observed and removal of a significant proportion of the insulin receptor $\beta$-subunits would likely result in a noticeable change in receptor affinity. The impairment of insulin-stimulated exogenous kinase activity of diabetic-derived receptors (Fig. 3) was more evident than that of the insulin activated autophosphorylation (Fig. 2). Preliminary data (39) suggest that phosphorylation of different tyrosyl sites on the $\beta$-subunit may not be equally important for the activation of the exogenous kinase.

Our results are in essential agreement with those reported by Kadowaki et al. (36) who showed impaired autophosphorylation of the insulin receptors derived from livers of streptozotocin-diabetic rats and by the recent report of decreased autophosphorylation in skeletal muscle from rats rendered diabetic by gold thioglucose treatment (40). The latter report suggests that the defect in the insulin receptor kinase activity is secondary to the diabetic state and not due to insulinopenia per se because the rats in Reference 40 were hyperinsulinemic. However, Amatruda et al. (41) isolated hepatic plasma membranes from diabetic rats and found no defect in insulin-stimulated receptor autophosphorylation. Whether or not the insulin receptor population that manifests diabetes related structural and functional alterations is actually present on the plasmalemma or represents an intracellular species requires further investigation.

The phosphopeptides generated by treating the isolated $\beta$ - subunit with TPCK-treated trypsin appeared identical in the diabetic and control muscle-derived receptors. We consistently generated 10 or more phosphopeptides from immunoprecipitated, electroeluted $\beta$-subunits even after digesting for $72 \mathrm{~h}$. Previous studies utilizing high performance liquid chromatography to separate the products of trypsin digestion reported the isolation of three to five phosphopeptides $(27,35)$. Whether the larger number observed in our system is due to incomplete digestion or to receptor heterogeneity or to the higher sensitivity of autoradiography after two-dimensional peptide separation is not clear. Visual analysis of these maps failed to reveal salient differences in the relative phosphorylation of these fragments between controls and diabetics. The receptors used in generating these maps were phosphorylated for $10 \mathrm{~min}$ at $25^{\circ} \mathrm{C}$ in order to maximize ${ }^{32} \mathrm{P}$ incorporation for visualization of phosphopeptides. However, a more detailed, quantitative examination of the phosphopeptides separated from receptors autophosphorylated at lower temperatures or for shorter time periods at $25^{\circ} \mathrm{C}$ may reveal differences between the two populations.

The presence of a subpopulation of insulin receptor $\beta$-subunits in diabetic rat skeletal muscle with retarded migration on SDS-PAGE suggests that diabetes affects the processing of the insulin receptor in muscle. We were able to detect this subpopulation of receptors in some rats $24 \mathrm{~h}$ after streptozotocin injection and in most animals by $3 \mathrm{~d}$. In some animals this slower migrating species comprised up to $50 \%$ of the phosphorylated $\beta$-subunit band detected by autoradiography. It was difficult to discern this altered population consistently on a $7.5 \%$ polyacrylamide gel; however, it became distinct after limited proteolytic digestion of the insulin receptor with V8 protease. This is likely due to the inverse logarithmic relationship between molecular weight and relative mobility on isocratic polyacrylamide gels resulting in improved resolution of smaller proteins, as well as the increased relative preponderance of the component with decreased mobility in the fragments. The changes in the insulin receptor $\beta$-subunit structure appear to be in response to insulinopenia and/or resulting changes in the metabolic milieu rather than to toxic effects of streptozotocin in that the slower migrating component was reduced or eliminated by $60 \mathrm{~h}$ of insulin treatment which normalized blood sugar. It is interesting to note that $\sim 10 \%$ of control animals studied demonstrated a small amount (most $<10 \%$ ) of a higher molecular weight subpopulation.

The glycoprotein nature of the insulin receptor has been demonstrated by direct labeling of the sugar moiety $(33,42)$ and indirectly by its ability to bind to lectins (43). Ronnett et al. (33) observed that the insulin receptor is synthesized as a single polypeptide chain, which is cleaved and subsequently glycosylated on both the $\alpha$ - and $\beta$-subunits. These intermediates are sensitive to endoglycosidase $\mathbf{H}$ and neuraminidase resistant. Salzman et al. (44) and Herzberg et al. (45) reported that the mature $\alpha$ - and $\beta$-subunits from 3T3-L1 adipocytes and IM-9 lymphocytes contain both endoglycosidase $\mathrm{H}$-sensitive and -insensitive sugar side chains. The latter report also showed that endoglycosidase $F$ could not remove all the sugar side chains from the $\beta$-subunit but treatment with a chemical deglycosylating agent resulted in an additional decrease in molecular weight suggesting the presence of $O$-linked side chains. The insulin receptor $\beta$-subunit isolated here from skeletal muscle of control or diabetic rats appeared to be sensitive to digestion by endoglycosidase $\mathbf{H}$; on autoradiography the 95,000-band migrated at $\sim 89,000$ after endoglycosidase $\mathrm{H}$ treatment, suggesting that the $\beta$-subunit isolated from skeletal muscle also contains "high mannose" oli- 
gosaccharide side chains. The peptides generated after V8 digestion, especially the prominent 54,000 band was also endoglycosidase $\mathrm{H}$-sensitive. The diabetic-derived $\beta$-subunit population separated into two distinct bands after V8 protease and endoglycosidase $\mathrm{H}$ treatment, one that comigrated with the control and one with $\sim 1,500$ higher $\mathrm{MW}_{\text {app }}$ (Fig. $8 b$ ). The further improvement in the resolution of the diabetes induced $\beta$-subunit populations after endoglycosidase $\mathbf{H}$ treatment likely reflects the elimination of oligosaccharides which are known to affect protein migration on SDS-PAGE (46). Treatment of the immunoprecipitated, insulin receptor populations with neuraminidase increased the migration of the diabetic-derived $\beta$-subunit more than that of the control, especially that of the prominent 54,000 peptide fragment (Fig. 9). This suggested that the heterogeneity of the diabetic-derived $\beta$-subunit was due in part to an increase in its sialic acid content. When V8-digested insulin receptors were treated with neuraminidase followed by endoglycosidase $\mathrm{H}$, the more slowly migrating component of the $\sim 54,000$ fragment (seen in diabetic derived $\beta$-subunits) appeared to decrease in molecular weight whereas the "control band" did not change its migratory behavior (Fig. 10). This suggests that there may be an additional sugar side chain on some diabetic-derived $\beta$-subunits or an alteration in the structure of one or more normally occurring oligosaccharide side chains. We encountered difficulties similar to those of Herzberg et al. (45) in attempting to completely remove the oligosaccharide side chains from the $\beta$ subunit with endoglycosidase $F$ or glycanase (broad spectrum $N$-linked glycosidases [Burant and Buse, unpublished observations] suggesting that the $\beta$-subunit may have $O$-linked sugar side chains.

Streptozotocin diabetes results in decreased sialic acid and other carbohydrate content of major glycoproteins on hepatocyte membranes (47) as well as decreased activity of certain glycosyltransferase enzymes, without a detectable change in sialyltransferase activity (48). The insulin receptor, however, is spared from the diabetes-associated decline in hepatic membrane glycoproteins, because hepatic insulin binding and receptor number appear to increase in insulinopenic diabetes $(13,36)$. The mechanism for the selectivity in hepatic glycoprotein synthesis or degradation is not understood; to our knowledge there is no information concerning the effect of diabetes on glycoprotein turnover or sialyltransferase activity in muscle. We did, however, see in diabetic rats a decline in the amount of glycoprotein per gram of muscle eluted from the wheat germ columns in the insulin receptor purification protocol.

In our studies, there appeared to be a relationship between the appearance of the $\beta$-subunit population with decreased electrophoretic mobility and changes in tyrosyl-kinase activitv, whenever one phenomenon was detected, so was the other. It is tempting to speculate that the metabolic alterations associated with insulin deficiency result in conformational changes in the receptor that renders the coupling between insulin binding and autophosphorylation less efficient. The precise relationship, if any, between the observed alteration in the kinase kinetics in the diabetic-derived insulin receptor and the structural heterogeneity of the $\beta$-subunit remains to be defined. Yamaguchi et al. (49) recently reported that neuraminidase treatment of highly purified placental insulin receptors increased insulin binding and tyrosine kinase activity. This observation suggests that alterations in sugar side chains may indeed modulate insulin receptor function.

The insulin resistance which accompanies poorly controlled insulinopenic diabetes involves both the liver and peripheral tissues; skeletal muscle has been implicated as the primary site (4). The work of Kadowaki et al. (36) in liver and the present work in skeletal muscle suggest that diabetes-induced changes in the $\beta$-subunit of the insulin receptor may play a role in this insulin resistance. In recent years there has been increasing awareness that insulin resistance associated with different pathologic conditions is caused to variable degrees by a defect in the binding of insulin to its targets, or to defects which occur after insulin binding. The latter abnormalities are generally referred to as postreceptor defects, with the tacit implication that they are distal to the receptor, involve the intracellular metabolic milieu, second messengers or their intracellular targets. Our data as well as those of others $(36,39)$, including a rare genetic defect of the insulin receptor $(50,51)$ suggest that postbinding defects may include "intrareceptor" defects, resulting in defective signalling by the receptor in response to hormone binding.

\section{Acknowledgments}

The authors wish to thank Drs. Steve Jacobs and C. Ronald Kahn for generous gifts of antiinsulin receptor antibodies, Drs. Ronald Chance and Bruce $\mathrm{H}$. Frank for gifts of monocomponent and A14 ${ }^{125} \mathrm{I}$-insulin respectively, Dr. George Lindenmayer for critical reading of the manuscript, Dr. Gary Landreth for stimulating discussions, and Ms. Barbara Whitlock for excellent secretarial assistance.

These investigations were supported in part by grant AM-02001 to Dr. Buse from the National Institutes of Health and a grant to Mr. Burant from the South Carolina Affiliate of the American Diabetes Association. C. F. Burant is supported by the Medical Scientist Training Program of the Medical University of South Carolina.

\section{References}

1. Himsworth, H. P., and R. B. Keer. 1939. Insulin-sensitive and insulin-insensitive types of diabetes mellitus. Clin. Sci. 4:119-152.

2. Martin, F. I. R., and A. E. Stocks. 1961. Insulin-sensitivity and ${ }^{131}$ I-metabolism in juvenile-type diabetes. Aust. Ann. Med. 16:289-296.

3. Harano, Y., S. Ohgaku, H. Hidaka, K. Hareda, R. K. Kikkawa, Y. Shigeta, and H. Abe. 1977. Glucose, insulin and somatostatin infusion for the determination of insulin sensitivity. J. Clin. Endocrinol. Metab. 45:1124-1127.

4. DeFronzo, R. A., R. Hendler, and D. Simonson. 1983. Insulinresistance is a prominent feature of insulin-dependent diabetes. Diabetes. 31:795-801.

5. Mayfield, R. K., F. M. Sullivan, J. A. Colwell, and H. J. Wohltmann. 1983. Predicting insulin requirements for a portable insulin pump using the biostator. Diabetes. 32:908-914.

6. Foss, M. C., F. V. Vlachokosta, L. N. Cunningham, and T. T. Aoki. 1982. Restoration of glucose homeostasis in insulin-dependent diabetic subjects: an inducible process. Diabetes. 31:46-52.

7. Sherwin, R. S., W. V. Tamborlane, M. Genel, and P. Felig. 1980. Treatment of juvenile-onset diabetes by subcutaneous infusion of insulin with a portable pump. Diabetes Care. 3:301-308.

8. Reaven, G. M., N. S. Sagemen, and R. S. Swenson. 1977. Development of insulin resistance in normal dogs following alloxan-induced insulin deficiency. Diabetologia. 13:459-462.

9. Kasuga, M. Y., Akanuma, Y, Iwamoto, K. Kosaka. 1978. Insulin binding and glucose metabolism in adipocytes from streptozotocin-diabetic rats. Am. J. Physiol. 235:E175-E182.

10. Kobayashi, M., and J. M. Olefsky. 1979. Effects of streptozotocininduced diabetes on insulin binding, glucose transport, and intracellular glucose metabolism in isolated rat adipocytes. Diabetes. 28:87-95.

11. Kaenieki, E., P. J. Hissin, I. A. Simpson, L. B. Salans, and S. W. Cushmann. 1981. A possible mechanism of insulin resistance in the rat 
adipose cell in streptozotocin-induced diabetes mellitus. J. Clin. Invest. 68:811-814.

12. Haft, D. E. 1968. Studies of the metabolism of livers of normal and alloxan-diabetic rats perfused with insulin. Diabetes. 17:244-250.

13. LeMarchand, Y., E. G. Loten, F. Assimacopoulos-Jeannet, M. E. Forgue, P. Freychet, and B. Jeanrenaud. 1976. Effects of fasting and streptozotocin on the obese-hyperglycemic (ob/ob) mouse. Diabetes. 26:582-590.

14. Kipnis, D. M., and C. F. Cori. 1959. Studies of tissue permeability. V. The penetration and phosphorylation of 2-deoxyglucose in the rat diaphragm. J. Biol. Chem. 234:171-177.

15. Morgan, H. E., E. Cadenas, D. M. Regen, and C. R. Park. 1961. Regulation of glucose uptake in muscle. II. Rate limiting steps and effects of insulin and anoxia in heart muscle from diabetic rats. J. Biol. Chem. 236:262-268.

16. Kasuga, M., F. A. Karlsson, and C. R. Kahn. 1982. Insulin stimulates the phosphorylation of the 95,000 dalton subunit of the insulin receptor. Science (Wash. DC). 215:185-187.

17. Kasuga, M., Y. Zick, D. C. Blithe, F. A. Karlsson, H. Haring, and C. R. Kahn. 1982. Insulin stimulates the phosphorylation of the $\beta$ subunit of the insulin receptor. J. Biol. Chem. 257:9891-9894.

18. Rosen, O. M., R. Herrera, Y. Olowe, L. M. Petruzzelli, and M. H. Cobb. 1983. Phosphorylation activates the insulin receptor tyrosine protein kinase. Proc. Natl. Acad. Sci. USA. 80:3237-3240.

19. Avruch, J., R. A. Nemenoff, P. J. Blackshear, M. W. Pierce, and R. Osathanondh. 1982. Insulin stimulates tyrosine phosphorylation of the insulin receptor in detergent extracts of human placental membranes. J. Biol. Chem. 257:15162-15166.

20. Van Obberghen, E., B. Rossi, A. Kowalski, H. Ganzzano, and C. Ponzio. 1983. Receptor-mediated phosphorylation of the hepatic insulin receptor: evidence that the MW 95000 receptor subunit is its own kinase. Proc. Natl. Acad. Sci. USA. 80:945-949.

21. Zick, Y., J. Wittaker, and J. Roth. 1983. The insulin receptor is coupled to tyrosine kinase activity. J. Biol. Chem. 259:3431-3434.

22. Kasuga, M., Y. Fijita-Yamaguchi, D. C. Glithe, and C. R. Kahn. 1983. Tyrosine-specific proten kinase activity is associated with the purified insulin receptor. Proc. Natl. Acad. Sci. USA. 80:2137-2141.

23. Burant, C. F., M. K. Treutelaar, G. E. Landreth, and M. G. Buse. 1984. Phosphorylation of the insulin receptor solubilized from rat skeletal muscle. Diabetes. 33:704-708.

24. Galbraith, R. A., C. Wise, and M. G. Buse. 1980. Insulin binding and response in erythroblastic leukemic cells. Diabetes. 29:571-578.

25. Taylor, S. E., J. A. Hedo, L. H. Underhill, M. Kasuga, M. J. Elders, and J. Roth. 1982. Extreme insulin resistance in association with abnormally high binding affinity of insulin receptors from a patient with leprechaunism: evidence for a defect intrinsic to the receptor. J. Clin. Endocrinol. Metab. 55:1108-1113.

26. Bradford, M. M. 1976. A rapid and sensitive method for quantitation of microgram quantities of protein utilizing the principle of protein-binding. Anal. Biochem. 72:248-254.

27. Yu, K.-T., and M. P. Czech. 1984. Tyrosine phosphorylation of the insulin receptor $\beta$-subunit activates the receptor-associated tyrosine kinase activity. J. Biol. Chem. 259:5277-5286.

28. Folley, L. S., S. D. Poner, and R. O. Poyton. 1983. Separation of nucleotides by ion pair, reverse-phase high-performance liquid chromatography. J. Chromatogr. 281:199-207.

29. Pilch, P. F., and M. P. Czech. 1979. Interaction of crosslinking agents with the insulin effector system of isolated fat cells. J. Biol. Chem. 254:3375-3381.

30. Cooper, J. A., B. M. Sefton, and T. Hunter. 1983. Detection and quantitation of phosphotyrosine in proteins. Methods Enzymol. 99:387403.

31. Beeman, K., and T. Hunter. 1978. Characterization of Rous sarcoma virus src gene products synthesized in vitro. J. Virol. 28:551566.
32. Carlin, C. R., and B. B. Knowles. 1984. Biosynthesis of epidermal growth factor receptor in human epidermoid carcinoma derived A431 cells. J. Biol. Chem. 259:7902-7908.

33. G. V. Ronnett, V. P. Knutson, R. A. Kohanski, T. C. Simpson and M. D. Lane. 1984. Role of glycosylation in the processing of newly translated insulin proreceptor in 3T3-L1 adipocytes. J. Biol. Chem. 259: 4566-4575.

34. Laemmli, V. K. Cleavage of structural proteins during the assembly of the head of bacteriophage T4. 1970. Nature (Lond.). 227:57178.

35. White, M. F., H. U. Haring, M. Kasuga, and C. R. Kahn. 1984 Kinetic properties and sites of autophosphorylation of the partially purified insulin receptor from hepatoma cells. J. Biol. Chem. 259:255-264.

36. Kadowaki, T., M. Kasuga, Y. Akanuma, O. Ezaki, and F. Takaku. 1984. Decreased autophosphorylation of the insulin receptor kinase in streptozotocin-diabetic rats. J. Biol. Chem. 259:14208-14216.

37. Okamoto, M., H. Kuzuya, and H. Imura. 1984. Increased affinity of insulin receptors on hepatocytes from streptozotocin-induced diabetic rats. Endocrinol. Jpn. 31:235-243.

38. LeMarchand-Brustel, Y., and P. Freychet. 1979. Effect of fasting and streptozotocin diabetes on insulin binding and action in the isolated mouse soleus muscle. J. Clin. Invest. 64:1505-1515.

39. Goren, H. J., and M. F. White. 1985. Mapping domains of the $\beta$-subunit of the insulin receptor. Diabetes. 34(Suppl. 1):55A. (Abstr.)

40. LeMarchand-Brustel, Y., T. Gremeaux, R. Ballotte, and E. Van Obberghen. 1985. Insulin receptor tyrosine kinase is defective in skeletal muscle of insulinresistant obese mice. Nature (Lond.). 315:676-679.

41. Amatruda, J. M., and A. M. Roncone. 1985. Normal hepatic insulin receptor autophosphorylation in non-ketotic diabetes mellitus. Biochem. Biophys. Res. Commun. 129:163-170.

42. Hedo, J. A., M. Kasuga, G. VanObberghen, J. Roth, and C. R. Kahn. 1981. Direct demonstration of glycosylation of insulin receptor subunits by biosynthetic and external labelling: evidence for heterogeneity. Proc. Natl. Acad. Sci. USA. 78:4291-4795.

43. Hedo, J., L. C. Harrison, and J. Roth. 1981. Binding of insulin receptors to lectins. Evidence for common carbohydrate determinants on several membrane receptors. Biochemistry. 20:3385-3393.

44. Salzman, H., C. F. Wan, C. S. Rubin. 1984. Biogenesis, transit and functional properties of the insulin proreceptor and modified insulin receptors in 3T3-L1 adipocytes. Use of monensin to probe proreceptor cleavage and generate altered receptor subunits. Biochemistry. 23:65556565 .

45. Herzberg, V. L., F. Grigorescu, A. S. B. Edge, R. Spiro, and C. R. Kahn. 1985. Characterization of insulin receptor carbohydrate by comparison of chemical and enzymatic deglycosylation. Biochem. Biophys. Res. Commun. 129:789-796.

46. Bettelheim, F. A. 1977. Molecular weight determination and physical properties. In The Glycoconjugates. M. I. Horowitz and W. Pigman, editors. Academic Press, Inc. New York. 111-128.

47. Carter, J. R., and V. Chandramouli. 1981. Cell surface changes in diabetes. In Diabetes Mellitus. M. Brownlee, editor. Garland STPM Press, New York. 277-286.

48. Tepperman, H. M., J. DeWitt, and J. Tepperman. 1983. The effects of streptozotocin diabetes on the activities of rat liver glycosyltransferases. Diabetes. 32:412-415.

49. Yamaguchi, Y. F., Y. Sato, and S. Kathuria. 1985. Removal of sialic acids from the purified insulin receptor results in enhanced insulin binding and kinase activities. Biochem. Biophys. Res. Commun. 129: 739-745.

50. Grunberger, G., Y. Zick, and P. Gordon. 1984. Defect in phosphorylation of insulin receptors in cells from an insulin resistant patient with normal insulin binding. Science (Wash. DC). 223:932-934.

51. Grigorescu, F., J. S. Flier, and C. R. Kahn. 1984. Defect in insulin receptor phosphorylation in erythrocytes and fibroblasts associated with severe insulin resistance. J. Biol. Chem. 259:15003-15006. 